\title{
Obszary badań współczesnej informatologii (nauki o informacji)
}

\author{
Barbara Sosińska-Kalata \\ Instytut Informacji Naukowej i Studiów Bibliologicznych \\ Uniwersytet Warszawski
}

\begin{abstract}
Abstrakt
Cel/teza: Celem artykułu jest przedstawienie kierunków rozwoju pola badawczego nauki o informacji (informatologii), od momentu jej wyodrębnienia się jako samodzielnej dyscypliny naukowej po czasy najnowsze.

Koncepcja/metody badań: Na podstawie krytycznej analizy piśmiennictwa w chronologicznej kolejności przedyskutowano zmieniające się nazewnictwo dyscypliny i porównano kryjące się za tymi zmianami kolejne próby redefiniowania zadań i celów badawczych nauki o informacji. Prezentacja ewolucji koncepcji nauki o informacji stanowi tło dla przedyskutowania wyników analizy współczesnych nurtów badawczych w nauce o informacji, przeprowadzonej na próbie 361 artykułów opublikowanych w czterech najważniejszych dla tej dyscypliny badawczych czasopismach międzynarodowych: "Journal of American Society for Information Science and Technology”, "Journal of Information Science” i „Journal of Documentation” (2011-2012) oraz „Annual Review of Information Science and Technology" (2007-2011).

Wyniki i wnioski: Prześledzono kształtowanie się nauki o informacji od jej najwcześniejszej koncepcji sformułowanej przez Paula Otleta po współczesne interpretacyjne badania zachowań informacyjnych oraz próby integracji społecznej i technologicznej perspektywy badań informatologicznych. Zwrócono uwagę na narastającą multidyscyplinarność nauki o informacji oraz konsekwentny rozwój dwóch odrębnych obszarów badawczych: związanego z doskonaleniem technologii informacyjnej i skupionego na użytkowaniu informacji i zachowaniach informacyjnych. Mimo rosnącej różnorodności problematyki badawczej nauki o informacji jej niezmienną oś problemową stanowi zapewnianie skutecznego komunikowania utrwalonej wiedzy pomiędzy ludźmi w różnych środowiskach ich aktywności i przy użyciu możliwie najbardziej efektywnych metod i narzędzi. Analiza najnowszego piśmiennictwa dyscypliny potwierdziła, iż główne nurty badawcze stanowią nadal zagadnienia związane z rozwojem technologii informacyjnych i z poznawaniem zachowań informacyjnych oraz użytkowania informacji. Nie został natomiast jednoznacznie potwierdzony opisywany w literaturze zwrot ku badaniu zjawisk informacyjnych w świecie społecznym i w kontekście kulturowym. Badanie piśmiennictwa potwierdziło również wzrost zainteresowania teorią i metodologią nauki o informacji, co może być wyrazem rosnącej metodologicznej dojrzałości nauki o informacji, ale także obaw związanych z rozmywaniem się jej odrębności wśród coraz liczniejszych innych nauk, w których również podejmowane są badania współczesnych zjawisk informacyjnych.

Oryginalność/Wartość poznawcza: Artykuł porządkuje wiedzę o dotychczasowym rozwoju nauki o informacji, uzupełniając ją o opartą na badaniach empirycznych charakterystykę najnowszych tendencji w kształtowaniu jej pola badawczego.
\end{abstract}

Słowa kluczowe Informatologia. Definicje. Interdyscyplinarność. Nauka o informacji. Nurty badawcze. Pole badawcze. Problemy badawcze.

Otrzymany: 1 sierpnia 2013 Poprawiony: 18 listopada 2013 Zaakceptowany: 19 listopada 2013 


\section{Wstęp}

W 2002 r. Tom Wilson - od kilkudziesięciu lat prowadzący badania dotyczące zachowań informacyjnych użytkowników serwisów i systemów informacyjnych - pisał:

Odkad zajmuję się nauka o informacji szeroki świat badań informacyjnych jest w stanie ciagtych zmian, i pewnie byto tak też wcześniej (Wilson, 2002) ${ }^{1}$.

Informatologia (nauka o informacji) jest w stanie ciągłych zmian. Ewolucja problematyki badawczej następuje oczywiście w każdej dyscyplinie naukowej, jednak w przypadku nauki o informacji dynamika zmian dotyczących zjawisk i procesów, które są przedmiotem jej badań w ostatnim czasie wywołuje przekonanie o potrzebie głębszej refleksji nad aksjologią i programem badawczym tej dyscypliny. Na przykład, w książce wydanej z okazji 50-lecia Institute of Information Scientists, którego powstanie miało wielki wpływ na konsolidację środowiska badaczy nauki o informacji w Wielkiej Brytanii, Jack Meadows zwracał uwagę na wpływ upowszechnienia serwisów informacyjnych na uwidaczniającą się obecnie dezintegrację dyscypliny:

(...) dziatania nauki o informacji rozwijane w ciagu minionych 50 lat triumfuja, ale nauka o informacji jako odrębna dziatalność (dyscyplina) może stabnać (Meadows, 2009 p. 17)².

Z kolei na konferencji „Nauka o informacji (informacja naukowa) w okresie zmian”, zorganizowanej w 2011 r. przez Instytut Informacji Naukowej i Studiów Bibliologicznych Uw w Warszawie, Dave Nicholas podkreślał niezbędność rewizji koncepcji i metod badań dotyczących użytkowników informacji i ich zachowań informacyjnych:

Zawód [specjalisty informacji] zostat uderzony przez informacyjne tsunami (...). Zanim badacze nauki o informacji solidnie rozpoznaja tę sytuacje - monitorujac i oceniajac cyfrowych użytkowników w sposób, jaki nigdy wcześniej nie byt możliwy i odrzuca przestarzate myślenie o tym jak ludzie używaja i poszukuja informacji, stoimy w obliczu perspektywy coraz mniejszej wiedzy o coraz większej liczbie ludzi (szczególnie urodzonych $w$ czasach cyfrowych, młodych ludzi) (Nicholas, 2013, p. 18-19)3.

W kontekście tych obserwacji w niniejszym artykule podejmuję próbę nakreślenia najważniejszych nurtów badań podejmowanych w niej w ostatnich latach. Ocena przekształceń dokonujących się w polu badawczym nauki o informacji wymaga jednak szerszej refleksji, dotyczącej identyfikacji problemów naukowych, które są dla tej nauki specyficzne. Nie jest to i nigdy nie było zadanie proste i bezdyskusyjne, właśnie ze względu na tę wielką dynamikę

${ }^{1}$ The wide world of information research has been in a state of continuous change ever since I became involved in it - and certainly before.

2 The overall result is that the information science activities developer over past 50 years have triumphed, but information science as a separate entity May be on the wane.

${ }^{3}$ The profession has been hit by an information tsunami so the topic of the conference Information Science in Change is very relevant and timely. Unless information science researchers get a firm grip on the situation - monitor and evaluate digital users in a way they have never done before and jettison obsolete thinking about how people use and seek information, we face the prospect of knowing less and less about more and more people (especially the born digital, the young). 
ewolucji przedmiotów badań informatologii, a także specyficzną dla niej multidyscyplinarność, która z jednej strony jest siłą napędową rozwoju pola badawczego dyscypliny, jednak z drugiej implikuje rozmywanie granic między badaniami informatologicznymi a obszarem badań innych nauk. Rosnąca rola dostępu do informacji i wszechobecność technologii informacyjnych we współczesnym świecie wymagają ich coraz bardziej wszechstronnego analizowania. W konsekwencji jednak to, czym nauka o informacji 20 lat temu zajmowała się jako niemal jedyna dyscyplina badawcza, dziś jest przedmiotem zainteresowania również wielu innych nauk.

Prezentacja wyników analizy współczesnych nurtów badawczych w nauce o informacji poprzedzam więc próbą naszkicowania ewolucji konceptualizacji informatologii (nauki o informacji), która pozwoli spojrzeć na wyniki tej analizy w szerszym kontekście przemian następujących w tej nauce od jej wyodrębnienia się do chwili obecnej.

\section{Czym jest nauka o informacji (informatologia)?}

Nauka, która w polskim nazewnictwie przypisane miała kolejno nazwy „dokumentacja naukowa”, następnie „informacja naukowa” i od 2010 r. „informatologia”, powstaje od ponad 100 lat. Ciągłe weryfikowanie właściwego zdefiniowania zadań tej nauki i poszukiwanie najtrafniejszego określenia jej tożsamości znajdują wyraz właśnie m.in. w licznych przeformułowaniach jej nazwy (por. Schrader, 1984). Tabela 1 prezentuje przybliżoną chronologię zmian tej nomenklatury w piśmiennictwie anglojęzycznym i polskim. Czcionką pogrubioną zaznaczone są nazwy o trwalszym funkcjonowaniu.

W europejskiej tradycji badawczej, ukierunkowanej w większym stopniu na metodologiczne i społeczne problemy dostępu do utrwalonej informacji i wiedzy, a w mniejszym na jego aspekty technologiczne, naukę o informacji traktuje się zwykle jako kontynuację stopniowo rozwijającej się refleksji teoretycznej związanej z kształtującą się od połowy XIX w. specjalistyczną działalnością bibliograficzną i później dokumentacyjną, powstawaniem specjalistycznych bibliotek i ośrodków dokumentacji tworzonych w środowisku pozabibliotecznym (stowarzyszeń naukowych i zawodowych, ośrodków badawczych), utworzeniem w 1885 r. przez Paula Otleta i Henri La Fontaine'a Institute International de Bibliographie w Brukseli (przekształconego później w najważniejszą aż do 2002 r. międzynarodową organizację w zakresie informacji i dokumentacji FID - Fédération International de Documentation, od 1986 r. Fédération International d'Information et de Documentation), powstaniem w Anglii w 1924 r. ASLIB (Association of Special Libraries and Information Bureaux, od lat 80. xx w. działającego pod nazwą ASLIB the Association for Information Management). Dodać warto, że od 1947 r. ASLIB publikuje najstarsze czasopismo informatologiczne - „Journal of Documentation”.

Chociaż w świecie anglosaskim genezę nauki o informacji wiąże się najczęściej z pierwszymi zastosowaniami komputerów do przetwarzania informacji tekstowej, warto przypomnieć, że także w USA dokumentacja zaczęła się rozwijać już w latach 30. xx w. W 1935 r. Watson Davis założył Documentation Institute, który dwa lata później zmienił nazwę na American Documentation Institute. W 1966 r. nastąpiła znamienna zmiana nazwy tej organizacji na American Society for Information Science (ASIS), a od 2000 r. do 2013 działała ona jako American Society for Information Science and Technology (ASIS\&T). Od 
1950 r. organizacja ta wydaje najważniejsze międzynarodowe czasopismo naukowe w tej dziedzinie - do 1968 r. pod tytułem „American Documentation”, następnie „Journal of the American Society for Information Science” (JASIS), a od 2000 r. "Journal of the American Society for Information Science and Technology” (JASIST). Po rozwiązaniu FID w 2002 r. ASIS\&T stało się najważniejszą organizację informatologiczną na świecie, skupiającą badaczy z różnych krajów, stąd od 2013 r. funkcjonuje ono pod zmienioną nazwą ASIS\&T - the Association for Information Science and Technology (Cronin, 2012, ASIS\&T, 2013).

Tabela 1. Chronologia zmian nazw nauki o informacji

\begin{tabular}{|c|c|c|c|}
\hline $\begin{array}{l}\text { NAZEWNICTWO } \\
\text { ANGIELSKIE }\end{array}$ & $\begin{array}{l}\text { OD } \\
\text { ROKU }\end{array}$ & $\begin{array}{l}\text { NAZEWNICTWO } \\
\text { POLSKIE }\end{array}$ & $\begin{array}{l}\text { OD } \\
\text { ROKU }\end{array}$ \\
\hline Bibliography & ok. 1800 & Bibliografia & ok. 1800 \\
\hline Documentation & ok. 1900 & Dokumentacja & ok. 1900 \\
\hline Information Technology & ok. 1945 & $\begin{array}{l}\text { Dokumentacja naukowa, } \\
\text { dokumentacja naukowo-tech- } \\
\text { niczne }\end{array}$ & ok. 1950 \\
\hline Scientific Information & ok. 1948 & \multirow{3}{*}{ Informacja naukowa, inte } & \multirow{3}{*}{ ok. 1965} \\
\hline $\begin{array}{l}\text { Information Science, } \\
\text { Information Sciences }\end{array}$ & ok. 1955 & & \\
\hline $\begin{array}{l}\text { Communication Studies, } \\
\text { Media Studies }\end{array}$ & ok. 1960 & & \\
\hline $\begin{array}{l}\text { Informatics, } \\
\text { Social Informatics }\end{array}$ & $\begin{array}{l}\text { ok. } 1960 / \\
1990\end{array}$ & $\begin{array}{l}\text { Informatyka prawnicza } \\
\text { (F. Studnicki) }\end{array}$ & ok. 1970 \\
\hline $\begin{array}{l}\text { Information Studies, } \\
\text { Information Research }\end{array}$ & ok. 1970 & $\begin{array}{l}\text { Informatologia, informatoryka, } \\
\text { informologia, informatyka }\end{array}$ & $\begin{array}{l}1974 / 77 \\
2010\end{array}$ \\
\hline Cultural Studies & ok. 1970 & $\begin{array}{l}\text { Nauka o informacji, } \\
\text { nauki o informacji }\end{array}$ & ok. 1995 \\
\hline Information Management & ok. 1975 & Zarządzanie informacją & ok. 2000 \\
\hline $\begin{array}{l}\text { Knowledge Management, } \\
\text { Information and Knowledge } \\
\text { Management }\end{array}$ & ok. 1995 & $\begin{array}{l}\text { Zarządzanie wiedzą, } \\
\text { Zarządzanie informacją } \\
\text { i wiedzą }\end{array}$ & ok. 2005 \\
\hline $\begin{array}{l}\text { Information Disciplines: } \\
\text { Archive, Library and Museum } \\
\text { Studies; Digital Humanities }\end{array}$ & ok. 2000 & $\begin{array}{l}\text { Informatyka medyczna, } \\
\text { informatyka chemiczna... }\end{array}$ & ok. 2000 \\
\hline
\end{tabular}

W Polsce pierwszymi organizacjami zajmującymi się działalnością dokumentacyjną i równocześnie rozwijającymi refleksję metodologiczną z nią związaną, były Sekcja Bibliograficzna Komitetu Bibliotecznego powstałego w 1898 r. przy Stowarzyszeniu Techników Polskich oraz Instytut Bibliograficzny zorganizowany w 1908 r. przy Towarzystwie Biblioteki Publicznej w Warszawie. Obie te organizacje od początku włączyły się we współpracę z brukselskim IIB, a następnie FID.

Z szerszej, europejskiej perspektywy patrzenia na dzieje nauki o informacji, która notabene ostatnio zyskuje coraz więcej propagatorów także w krajach anglosaskich, za pierwszą monografię poświęconą tej dyscyplinie uznaje się dzieło Paula Otleta, Traité de 
documentation. Le livre sur le livre. Théorie et pratique, wydane w 1934 r. Zamieszczoną tam definicję dokumentacji można uznać za pierwszą próbę nakreślenia zakresu problemów badanych przez naukę, która ma stanowić teoretyczną podstawę praktyki dokumentacyjnej. Problemy te odnoszą się do zadań dokumentacji, które Otlet określił następująco:

Zadania dokumentacji polegaja na oferowaniu informacji o wszelkiego rodzaju udokumentowanych faktach $i$ wiedzy naukowej, które są: (1) uniwersalne pod względem zakresu przedmiotowego;

(2) pewne i prawdziwe; (3) kompletne; (4) dostarczane szybko; (5) aktualne; (6) tatwo dostepne;

(7) wcześniej zgromadzone i przygotowane do przekazania; (8) do dyspozycji jak najszerszego grona użytkowników (Otlet, 1934, s. 6) $)^{4}$.

Dyscyplina naukowa, nazywana w Traité dokumentologią (fr. documentologie) czy też bibliologią (fr. bibliologie), przez którą Otlet rozumiał naukę o książce jako dokumencie każdego rodzaju, miała zajmować się systematyzowaniem wiedzy dotyczącej zagadnień dokumentacji, określaniem jej pojęć, terminologii i jednostek pomiaru badanych zjawisk, a także ustalaniem jej związków z innymi naukami oraz badaniem jej historii (Otlet, 1934 s. 8; Dembowska, 1965 s.58).

W pierwszej polskiej monografii informatologicznej pt. Dokumentacja i informacja naukowa. Zarys problematyki i kierunki rozwoju Maria Dembowska zwracała uwagę na nowoczesny sposób patrzenia przez Otleta na dokumentację jako jedną z dziedzin organizacji nauki (Dembowska, 1965, s. 55). Warto zauważyć, że w świetle badań, których wyniki przedstawione są w dalszej części niniejszego artykułu, ścisły związek nauki o informacji z problematyką organizacji nauki, zwłaszcza komunikacji naukowej, szczególnie wyraźnie uwidacznia się współcześnie w kontekście wpływu komputerowych technologii informacyjnych na przekształcenia metod i form transferu wiedzy naukowej. Obecnie jest to jednak jeden z wielu nurtów badawczych informatologii.

Przypominając pierwszą próbę zdefiniowania informatologii trzeba zwrócić uwagę na dwie kwestie istotne dla koncepcji Otletowskiej tej dyscypliny. Po pierwsze, przeciwstawiając ją tradycyjnie pojmowanej działalności bibliograficznej prowadzonej w bibliotekach i skupionej na rejestrowaniu publikacji książkowych, Otlet uznając dokument za centralną kategorię pojęciową dokumentacji i dokumentologii zdefiniował go szeroko, obejmując tym pojęciem wszelkie formy utrwalenia wiedzy: zarówno książki i artykuły, jak i dokumenty ikonograficzne, zapisy dźwiękowe i filmowe, numizmaty i eksponaty muzealne. Po wtóre, w konsekwencji tego szerokiego pojmowania dokumentu Otlet postulował ujęcie działalności dokumentacyjnej we wszystkich obszarach w jeden spójny system, obejmujący wszystkie instytucje zajmujące się gromadzeniem, organizowaniem, przechowywaniem i udostępnianiem kolekcji różnych form utrwalenia ludzkiej wiedzy, a więc biblioteki, ośrodki bibliograficzne, archiwa i muzea (Otlet, 1934, s. 6-7). W tym szerokim sensie dokumentacja obejmuje więc wszystkie aspekty związane z zachowaniem i umożliwieniem korzystania z utrwalonej wiedzy dla różnych celów i potrzeb (Buckland, 1999 s. 971). Refleksja teoretyczna związana z działalnością dokumentacyjną skupia się u Otleta przede wszystkim na

\footnotetext{
${ }^{4}$ Les Buts de la Documentation organisée consistent à pouvoir offrir sur tout ordre de fait et de connaissance des informations documentés: $1^{\circ}$ universelles quant à leur objet; $2^{\circ}$ sûres et vraies; $3^{\circ}$ complètes; $4^{\circ}$ rapides; $5^{\circ}$ à jour; $6^{\circ}$ faciles à obtenir: $7^{\circ}$ réunies d'avance et prêtes à être communiquées; $8^{\circ}$ mises à la disposition du plus grand nombre.
} 
czterech obszarach: (i) konceptualnej organizacji dokumentowanej wiedzy, czyli jej klasyfikacji; (ii) organizacji warsztatu pracy dokumentalisty, w tym przede wszystkim standaryzacji metod i narzędzi związanych z gromadzeniem, przechowywaniem, opracowaniem, wyszukiwaniem, ekstrahowaniem i rozpowszechnianiem wiedzy zapisanej w dokumentach; (iii) współpracy między ośrodkami dokumentacyjnymi na świecie (sieć Mundaneum, tzw. „papierowy Internet”); (iv) rozwiązań technicznych, usprawniających szybkie i sprawne realizowanie zadań dokumentacji (rozwijanie technologii informacyjnej).

Za przełomowe dla kształtowania się nowoczesnej nauki o informacji w okresie powojennym uznaje się właśnie pojawienie się w końcu lat 40. i na początku lat 50. xx w. komputerowych technologii informacyjnych oraz pierwsze próby zastosowania ich do tworzenia systemów informacyjnych, umożliwiających szybkie przeszukiwanie nagromadzonych zasobów informacji o wynikach badań naukowych (w tym licznych raportów z badań utajnionych w okresie II wojny światowej), a także materiałów archiwalnych i dokumentacji wykorzystywanej w zarządzaniu w różnych obszarach działalności administracyjnej i gospodarczej. Poszukiwanie metod skutecznego zarządzania dokumentami tekstowymi w obu tych obszarach miało istotny wpływ na późniejsze i wykorzystywane do dzisiaj koncepcje tworzenia, strukturyzacji i przeszukiwania komputerowych baz danych. W 1945 r. po raz pierwszy na oznaczenie tej grupy zagadnień zaczęto stosować określenie Information Technology (Hjørland, 2011, s. 6). Dla wielu badaczy, zwłaszcza z kręgu anglosaskiego, ten właśnie okres stanowi początek współczesnej, technologicznie zorientowanej nauki o informacji, a najbardziej znanym przykładem badań należących do tego jej nurtu są słynne eksperymenty Cranfieldzkie, czyli badania efektywności wyszukiwania informacji za pomocą różnych języków informacyjnych, przeprowadzone w latach 1957-1965 przez zespół Cyrila Cleverdona w bibliotece College of Aeronautics w Cranfield w Wielkiej Brytanii (Cleverdon, 1991). Eksperymenty Cranfieldzkie zapoczątkowały rozwijany do dzisiaj model badań nad doskonaleniem narzędzi wyszukiwania informacji (ang. Information Retrieval), kontynuowany przez Gerarda Saltona i Michaela Leska w ramach projektu SMART (1961-1969) (Salton, 1975), a obecnie m.in. przez badania TREC (Text REtrieval Conference) prowadzone cyklicznie od 1992 r. (Manning et al., 2008). Problematyka wyszukiwania informacji, skupiona na zagadnieniach skutecznego przetwarzania tekstów językowych i technicznych aspektach operacji automatycznego wyodrębnia z ich zbiorów takich tekstów, które są semantycznie najbliższe zgłoszonym kwerendom, do dzisiaj jest jednym z najbardziej intensywnie eksplorowanych obszarów szeroko rozumianej nauki o informacji.

Z konferencją zorganizowaną w 1948 r. przez Royal Society w Londynie pod hasłem „Scientific Information Conference” wiąże się wprowadzenie do nomenklatury dyscypliny nazwy „informacja naukowa”, która w języku polskim przez kolejnych kilkadziesiąt lat, aż do 2010 r., była jej najczęściej używaną etykietą ogólną. Tymczasem w krajach anglosaskich i piśmiennictwie anglojęzycznym nazwa Scientific Information związana została z wchodzącą w zakres dyscypliny, ale nie wyczerpującą jej pola badawczego, problematyką działalności informacyjnej w nauce, która zresztą niezmiennie stanowi jeden z najważniejszych nurtów nauki o informacji. Działalności tej poświęcona była londyńska konferencja, zajmuje się nią m.in. Institute for Scientific Information założony w 1955 r. przez Eugene’a Garfielda w Filadelfii i wchodzący obecnie w skład korporacji Thomson Reuters, która prowadzi bazy ISI Web of Knowledge. Nad problematyką nowoczesnej organizacji tej działalności debatowano także na „International Conference for Scientific Information” w Waszyngtonie 
w 1958 r., zorganizowanej przez American Documentation Institute, Us National Science Foundation i UNESCO. Jest to druga z historycznych „konferencji założycielskich”, na których wyznaczony został program badań i działań związanych z rozwojem nowoczesnej dystrybucji informacji w nauce.

Maria Dembowska we wspomnianej już wcześniej książce Dokumentacja i informacja naukowa. Zarys problematyki i kierunki rozwoju zdefiniowała obszar zainteresowań tej dyscypliny następująco:

Przedmiotem tej gatęzi wiedzy jest działalność dokumentacyjno-informacyjna, tj. zespót procesów przekazywania informacji naukowych [podkreślenie BSK] i poszczególne procesy składające się na tę działalność. (...) [D]o przedmiotu badań należy również sama informacja naukowa i jej materialne podłoże (tj. dokumenty), środki i metody przekazywania informacji naukowej, systemy informacji i inne zagadnienia bezpośrednio zwiazane z tą działalnościq" (Dembowska, 1965, s. 111-112).

W takim ujęciu wyraźnie widoczne jest ukierunkowanie pola badawczego dyscypliny nazywanej tu informacją naukową na problematykę procesów informacyjnych związanych z nauką i służących komunikacji naukowej. Charakter informacji i procesów informacyjnych stanowiących przedmiot zainteresowań nauki o informacji systematycznie się jednak rozszerza. Już w latach 70 . xx w. także w polskim nazewnictwie instytucji odpowiadających za organizację działalności informacyjnej i prowadzenie badań z nią związanych nazwa „informacja naukowa” połączona została z dodatkowymi określeniami „techniczna i ekonomiczna” lub „techniczna i organizacyjna”, sygnalizującymi objęcie polem badawczym dyscypliny procesów związanych z transferem informacji zarówno w nauce, jak i w innych obszarach, w szczególności gospodarce i przemyśle. Tę szerszą interpretację polskiej nazwy „informacja naukowa” znajdziemy np.w Stowniku terminologicznym informacji naukowej pod redakcją M. Dembowskiej z 1978 r.:

informacja naukowa - (...) (4) dziedzina wiedzy obejmujaca całoksztatt zagadnień teoretycznych i praktycznych zwiazanych $z$ *działalnościa informacyjna (Dembowska, red. 1978, s. 54). dziatalność informacyjna zob. informacja inte (Dembowska, red. 1978, s. 41) informacja - inte (...) (3) zorganizowana dziatalność, której zadaniem jest gromadzenie, opracowywanie $i$ udostępnianie informacji o osiagnięciach nauki, techniki i innych dziedzin życia społecznego (Dembowska, red. 1978, s. 53).

Obok zagadnień organizacji, metod i technicznych narzędzi prowadzenia działalności informacyjnej jednym $\mathrm{z}$ wątków debat, które prowadzono już na wspomnianych międzynarodowych konferencjach poświęconych informacji naukowej w 1948 i 1958 r., były problemy związane z potrzebami użytkowników informacji, wykorzystaniem informacji oraz szkoleniem użytkowników do sprawnego korzystania z nowoczesnych usług i systemów informacyjnych. Niemal więc od początku powojennego rozwoju nauki o informacji również ta problematyka weszła w zakres jej badań, stopniowo zajmując w nich coraz ważniejsze miejsce. Oceniając tematykę badań prowadzonych w zakresie nauki o informacji naukowej, określanej już równolegle mianem informatologii, w 1991 r. Maria Dembowska pisała:

Przeważajaca część badań dotyczy metodyki prac dokumentacyjno-informacyjnych, organizacji systemów informacji, zastosowania nowoczesnych technik w procesach gromadzenia, opracowania, przetwarzania i udostępniania informacji. Mniej liczne są badania na temat użytkowników 
informacji, mimo podkreślania przez specjalistów wagi i znaczenia tych badań dla efektywności pracy informacyjnej (Dembowska, 1991, s. 14).

Podobnie zakres dyscypliny w 2002 r. zrelacjonowany został w Słowniku encyklopedycznym informacji, języków i systemów informacyjno-wyszukiwawczych, gdzie informacja naukowa zdefiniowana jest następująco:

dziedzina wiedzy zajmująca się systemami informacyjno-wyszukiwawczymi i ich użytkownikami, aspektami teoretycznymi, projektowaniem i funkcjonowaniem. Najważniejsze problemy to: teoria i projektowanie języków informacyjno-wyszukiwawczych, tworzenie zbiorów wyszukiwawczych systemów informacji dokumentacyjnej - tu przede wszystkim problemy opracowania dokumentów i informacji faktograficznej, opracowanie strategii wyszukiwawczych, optymalizacja dziatania systemów i poprawa efektywności systemów informacyjno-wyszukiwawczych, badania potrzeb informacyjnych użytkowników systemów informacyjno-wyszukiwawczych (Bojar., red., s. 90).

W piśmiennictwie anglojęzycznym już w połowie lat 50. xx w. coraz częściej używaną nazwą dyscypliny stało się określenie Information Science, które dziesięć lat później wyparło Documentation z nazwy głównej amerykańskiej organizacji naukowej tej dyscypliny oraz z tytułu wydawanego przez nią czasopisma. Określenie to upowszechniło się również w nazewnictwie wydziałów, szkół i programów studiów - najczęściej w połączeniu: Library and Information Scienc (LIS), a od lat 90. xx w. coraz częściej w inwersyjnym układzie Information and Library Science (ILS). Nazwa Information Science w anglojęzycznej nomeklaturze kierunków studiów, programów i instytucji naukowych często wchodzi także w związek z Computer Science tworząc frazę Computer and Information Science. Patrząc na naukę o informacji w najogólniejszej perspektywie można stwierdzić, że Information Science powiązana z Library Science i Information Science powiązana z Computer Science to ta sama interdyscyplinarna nauka, której centralnymi kategoriami poznawczymi są informacja i procesy informacyjne, analizowane w aspektach specyficznych bądź to dla potrzeb bibliotekoznawstwa, bibliografii, archiwistyki, czy szerzej - nauk o kulturze i komunikacji, zajmujących się zachowaniem i udostępnianiem zapisów ludzkiej wiedzy, bądź to zainteresowań informatyki, czy też nauki o przetwarzaniu komputerowym. Zakres problemów badawczych, na których rozwiązaniu skupia się uwaga badaczy związanych z tymi dwoma podejściami tylko częściowo na siebie zachodzi. Np. badanie jakości zasobów informacji i wiedzy udostępnianych poprzez systemy informacyjne lub badanie odbioru informacji przez człowieka są domeną nauki o informacji stanowiącej część nauk o kulturze, ale już modele i systemy wyszukiwania informacji leżą w polu zainteresowań nauki o informacji ujmowanej z obu perspektyw, choć z punktu widzenia informatyki przedmiotem dociekań są zwykle ogólne modele, struktury i algorytmy wyszukiwania, podczas gdy z punktu widzenia nauk o kulturze i komunikacji problemem pierwszoplanowym jest opracowanie struktur i modeli najbardziej użytecznych do wyszukiwania określonego rodzaju zapisów wiedzy dla określonych celów (por. Daniłowicz, 1994).

Jedną z najpopularniejszych definicji Information Science stała się propozycja Harolda Borko z 1968 r., która miała służyć rekonceptualizacji nauki o informacji po formalnym przyjęciu tej nowej nazwy przez American Society for Information Science:

Nauka o informacji (Information Science) jest dyscyplina badajaca własności i zachowanie informacji, sity rzadzace przeptywem informacji oraz środki przetwarzania informacji dla zapewnienia optymalnej jej dostępności i użyteczności. Dotyczy korpusu wiedzy zwiąanej z powstawaniem, gromadzeniem, organizowaniem, przechowywaniem, wyszukiwaniem, interpretacja, 
transmisja, transformacja oraz utylizacja informacji. Obejmuje badania reprezentacji informacji zarówno w naturalnych jak i sztucznych systemach, wykorzystania kodów dla sprawnej transmisji oraz badania urzadzeń $i$ technik takich jak komputery i programy komputerowe. Jest nauka interdyscyplinarna wywodzacq się $i$ zwiazana $z$ takimi dziedzinami jak matematyka, logika, lingwistyka, psychologia, technologia komputerowa, badania operacyjne, grafika, komunikacja, bibliotekoznawstwo, zarzadzanie i inne podobne dziedziny. Ma zarówno sktadnik nauk ścistych, który bada jej przedmiot bez względu na zastosowanie, jak $i$ sktadnik nauk stosowanych, który rozwija ustugi i produkty. (...) Nauka o informacji jako dyscyplina ma za cel dostarczenie informacji, które będa prowadzić do ulepszenia funkcjonowania wielu instytucji i procedur zwiazanych $z$ akumulacja $i$ transmisja wiedzy (Borko, 1968, s. 3). ${ }^{5}$

W takim ujęciu nauka o informacji jest właśnie szeroko pojmowaną interdyscyplinarną nauką badającą różnorodne aspekty informacji i procesów informacyjnych. Łatwo jednak dostrzec, że wśród jej związków z innymi dyscyplinami w pierwszej kolejności Borko wymienia matematykę i logikę, technologię komputerową oraz językoznawstwo i psychologię w tym zakresie, który obejmuje komputerowe przetwarzanie języka naturalnego oraz przetwarzanie informacji przez człowieka6. Nauka o informacji jest więc dyscypliną, która z jednej strony z tych trzech punktów widzenia (modeli formalnych, przetwarzania języka naturalnego i modeli poznawczych) bada naturę informacji i procesów informacyjnych, a z drugiej opracowuje metody i narzędzia przeznaczone do automatyzacji prac związanych z gromadzeniem, przetwarzaniem i przekazywaniem (udostępnianiem, rozpowszechnianiem) wiedzy w różnych środowiskach i dla różnych celów, wśród których jednym z najwcześniej eksplorowanych była naukowa działalność informacyjna uprawiana w bibliotekach.

W piśmiennictwie informatologicznym do definicji Borko świadomie lub nieświadomie nawiązuje się bardzo często, zwykle jednak ujmując ją w wersji skróconej, zredukowanej do pierwszych dwóch zdań oraz stwierdzenia o dwóch składnikach dyscypliny: ścistym i stosowanym. Bywa też, że ten drugi składnik zastępowany jest składnikiem społecznym, co jednak już wyraźnie odbiega od sensu definicji zaproponowanej przez Borko.

Na silny, konstytutywny związek nauki o informacji z technologią informacyjną kładł nacisk również Tefko Saracevic, zaznaczając równocześnie społeczny i komunikacyjny wymiar badań prowadzonych w tej nauce:

${ }^{5}$ Information Science is that discipline that investigate the properties and behavior of information, the forces governing the flow of information, and the means of processing information for optimum accessibility and usability. It is concerned of that body of knowledge related to the origination, collection, organization, storage, retrieval, interpretation, transmission, transformation, and utilization of information. This includes the investigation of information representation in both natural and artificial systems, the use of codes for efficient message transmission, and the study of information processing devices and techniques such as computers and their programming systems. It is an interdisciplinary science derived from and related to such fields as mathematics, logic, linguistics, psychology, computer technology, operations research, the graphic arts, communications, library science, management and other similar fields. It has both pure science component, which inquires into the subject without regard to its application, and an applied science component, which develop services and products. (...) Information Science as a discipline has as its goal to provide a body of information that will lead to improvements in the various institutions and procedures dedicated to accumulation and transmission of knowledge.

${ }^{6}$ Zmarły w kwietniu $2012 \mathrm{r}$. Harold Borko znany jest w nauce o informacji przede wszystkim z prac w zakresie indeksowania, abstraktowania, klasyfikacji i wyszukiwania informacji. Warto przypomnieć jednak, że z wykształcenia był on psychologiem, a jego doktorat dotyczył psychometrii. 
Nauka o informacji (Information Science) ma trzy ogólne cechy charakterystyczne, które stanowia motyw przewodni jej ewolucji i istnienia. Dzieli je z wieloma innymi nowoczesnymi obszarami badań. Moga być one również postrzegane jako obszary problemów, z którymi nauka o informacji ma do czynienia na najogólniejszym poziomie.

Po pierwsze, nauka o informacji jest $z$ natury swej interdyscyplinarna; jednakże jej relacje z innymi dyscyplinami zmieniaja się. Jej interdyscyplinarnej ewolucji daleko jest do końca.

Po drugie, nauka o informacji jest niepowstrzymanie powiazana $z$ technologia informacyjna. Imperatyw technologiczny jest wymusza $i$ wyznacza ewolucję nauki o informacji, jak $i$ ewolucje wielu innych dyscyplin, co więcej, społeczeństwa informacyjnego jako całości.

Po trzecie, nauka o informacji jest, razem $z$ wieloma innymi dyscyplinami, aktywnym uczestnikiem ewolucji społeczeństwa informacyjnego. Nauka o informacji ma silny wymiar społeczny i ludzki, wykraczajacy ponad i poza technologię informacyjna (Saracevic, 1999, s. 1052).?

Podobnie jak Borko, istotę odrębności nauki o informacji wobec wcześniejszych dyscyplin zajmujących się różnymi metodami przetwarzania informacji Saracevic widzi przede wszystkim w tym, iż nauka o informacji skupia uwagę na radykalnie innych sposobach przetwarzania informacji niż stosowane wcześniej, tj. na automatyzacji procesów informacyjnych, na komputerowej technologii informacyjnej, na narzędziach tzw. wysokich technologii. Centralnymi kategoriami badawczymi w tak pojmowanej nauce o informacji są: wyszukiwanie informacji jako proces realizowany przez komputer na podstawie logiki formalnej; relewancja jako kategoria łącząca ten proces z ludzkimi potrzebami informacyjnymi i oceną wyników wyszukiwania; interakcja jako proces umożliwiający bezpośrednią wymianę i sprzężenie zwrotne między systemami informacyjnymi i ludźmi zaangażowanymi w wyszukiwanie informacji. W definicji nauki o informacji przedstawionej przez Saracevica w jubileuszowym, 50. roczniku JAsıs główny problem, którego rozwiązaniu służą zarówno badania w tej dyscyplinie jak i wykorzystująca ich wyniki praktyka stanowi sprawny transfer wszelkiej utrwalonej wiedzy we wszelkiego rodzaju środowisku społecznym i organizacyjnym:

(...) nauka o informacji (Information Science) jest polem profesjonalnej działalności praktycznej $i$ badań naukowych dotyczacych problemu efektywnej komunikacji zapisów wiedzy - „literatury" - pomiędzy ludźmi w kontekście społecznych, organizacyjnych $i$ jednostkowych potrzeb $i$ wykorzystywania informacji. Główny kierunek badań wiaże się z problemem zapotrzebowania na informację i wykorzystywania informacji w odniesieniu do zapisów wiedzy. Dla zaspokojenia tego zapotrzebowania nauka o informacji odwotuje się do specjalnych technik informacyjnych, procedur i systemów (Saracevic, 1999, s. 1055-1056). ${ }^{8}$

${ }^{7}$ Information science has three general characteristics that are the leitmotif of its evolution and existence. These are shared with many modern fields. They can also be viewed as problem areas with which information science has to deal on a general level. (1) First, information science is interdisciplinary in nature; however, the relations with various disciplines are changing. The interdisciplinary evolution is far from over. (2) Second, information science is inexorably connected to information technology. A technological imperative is compelling and constraining the evolution of information science, as is the evolution of a number of other fields, and moreover, of the information society as a whole. (3) Third, information science is, with many other fields, an active participant in the evolution of the information society. Information science has a strong social and human dimension, above and beyond technology.

${ }^{8}$ (...) information science is a field of professional practice and scientific inquiry addressing the problem of effective communication of knowledge records - "literature"- among humans in the context of social, organizational, and individual need for and use of information. The key orientation here is the problem of need for and use of information, as involving knowledge records. To provide for that need, information science deals with specifically oriented information techniques, procedures, and systems. 
W tym samym jubileuszowym, 50. roczniku JA sıs Michael Buckland zwracał już uwagę na kształtowanie się w nauce o informacji $d w o ́ c h$ różnych tradycji badawczych, $d$ wóch rodzajów mentalności naukowych, albo też $d w o ́ c h$ koegzystujących w tej nauce kultur:

(1) tradycji dokumentacyjnej, tj. podejścia opartego na zainteresowaniu dokumentami, zapisami informacji - archiwami, bibliografią, dokumentacją, bibliotekoznawstwem, zarządzaniem dokumentami

(2) tradycji komputacyjnej, tj. podejścia opartego na szukaniu zastosowań dla formalnych technik, czy to mechanicznych (takich jak karty perforowane i urządzenia do przetwarzania danych), czy to matematycznych (takich jak procedury algorytmiczne (Buckland, 1999, s. 971). ${ }^{9}$

W czasach masowej cyfryzacji nurt nauki o informacji skupiony na dokumentach i procesach związanych z zapewnianiem do nich dostępu uległ wielkiemu poszerzeniu, obejmując badania dotyczące właściwie wszystkich form utrwalania i transmisji wiedzy. Przyczynia się to do coraz szerszej świadomości, że w swojej istocie badania tego nurtu nauki o informacji dotyczą rozmaitych form, narzędzi i aspektów przekazu kulturowego: wiedzy, znaczenia, uczenia się, języków i językowych opisów świata. Korzenie tych badań tkwią zatem w studiach nad kulturą i jakościowych badaniach społecznych. Z kolei coraz większa złożoność i coraz większa powszechność technologii informacyjnej wykorzystywanej do społecznego transferu informacji i wiedzy prowadzi do pewnego oddalania się komputacyjnego nurtu badań od nurtu skupionego na użytkowaniu informacji. Środowiska badawcze związane $z$ tymi dwoma nurtami badań nauki o informacji cechuje wyraźna odrębność, co dobrze ilustruja wyniki badań opublikowanych w 1998 r. przez Howarda White'a i Katherine Cain (White \& McCain, 1998). Na podstawie analizy cytowań zawartych w artykułach opublikowanych w 12 najważniejszych czasopismach w ciągu 24 lat (1972-1995), naszkicowali oni rozkład ko-cytowań dla 120 najczęściej cytowanych autorów, stwierdzając, $i \dot{z}$ we wszystkich trzech badanych okresach (1972-1979, 1980-1989 i 1989-1995) tworzq one dwa wyraźnie odrębne skupiska: jedno z nich tworzą badacze systemów informacyjnych i wyszukiwania informacji, drugie natomiast badacze problematyki wykorzystywania informacji i zachowań informacyjnych. Istnieje wprawdzie niewielka grupa autorów, których prace cytowane są przez badaczy z obu tych obszarów, a więc która stanowi swoisty pomost między tymi odrębnymi środowiskami, ale grupa ta we wszystkich analizowanych okresach jest nieliczna i stopniowo maleje.

Różnorodność pola badawczego nauki o informacji jest konsekwencją tego, że nauka ta nie ma jednorodnego przedmiotu badań. Fenomen informacji z natury rzeczy w różnych kontekstach i na różnych poziomach złożoności rozpatrywanej rzeczywistości, przyjmuje różne formy, stąd w różnych nurtach badań prowadzonych w nauce o informacji ten fenomen postrzegany jest różnie. Według T. Wilsona przedmiotem badań specjalistów wyszukiwania informacji jest informacja postrzegana jako ciągi znaków, dla których określa się warunki zgodności; w bibliometrii badaną informacją są dokumenty piśmiennicze, których

9 Although it is a considerable simplification, I think that it can be helpful to think in terms of two traditions, or mentalities, even cultures, that coexist in the area of Information Science: (1) approaches based on a concern with documents, with signifying records: archives, bibliography, documentation, librarianship, records management, and the like; and (2) approaches based on finding uses for formal techniques, whether mechanical (such as punch cards and data-processing equipment) or mathematical (as in algorithmic procedures). 
cytowanie w innych dokumentach pozwala mierzyć stopień ich wykorzystywania przez użytkowników zawartych w nich treści, a w badaniu zachowań informacyjnych - szeroko rozumiany zapis pewnych treści, którego poszukuje użytkownik informacji (Wilson, 2002).

Ta wewnętrzna niespójność pola badawczego informatologii jest też rezultatem równoległego rozwoju jej dwóch paradygmatów metodologicznych: chronologicznie wcześniejszego paradygmatu pozytywistyczny i nieco później zainicjowanego paradygmatu fenomenologicznego. Pierwszy cechuje dążenie do poznania obiektywnego, fizykalny i deskryptywny model rzeczywistości, poszukiwanie praw rządzących informacją i stosowanie ilościowych metod badawczych. Drugi akcentuje subiektywizm poznania, zakłada interpretatywny model rzeczywistości, opiera się na wyjaśnianiu indywidualnego doświadczania świata i stosuje jakościowe metody badawcze (por. Cisek, 2002, 2008; Sapa, 2013). Oba te paradygmaty obecne są w różnych obszarach badań nauki o informacji (tabela 2).

Tabela 2. Paradygmaty pozytywistyczny i fenomenologiczny w nauce o informacji

\begin{tabular}{|l|l|l|}
\hline \multicolumn{1}{|c|}{$\begin{array}{c}\text { OBSZAR BADAŃ NAUKI } \\
\text { O INFORMACJI }\end{array}$} & \multicolumn{1}{|c|}{$\begin{array}{c}\text { PARADYGMAT } \\
\text { POZYTYWISTYCZNY }\end{array}$} & \multicolumn{1}{c|}{$\begin{array}{c}\text { PARADYGMAT } \\
\text { FENOMENOLOGICZNY }\end{array}$} \\
\hline $\begin{array}{l}\text { Systemy informacyjne, } \\
\text { technologia informacyjna }\end{array}$ & $\begin{array}{l}\text { Efektywność wyszukiwania } \\
\text { informacji }\end{array}$ & $\begin{array}{l}\text { Modelowanie HCI (interakcji } \\
\text { człowiek-komputer) } \\
\text { Badanie użyteczności } \\
\text { (usability) }\end{array}$ \\
\hline Użytkowanie informacji & $\begin{array}{l}\text { Bibliometria } \\
\text { Webometria }\end{array}$ & $\begin{array}{l}\text { Badanie zachowań } \\
\text { informacyjnych } \\
\text { Szukanie sensów }\end{array}$ \\
\hline Komunikacja naukowa & $\begin{array}{l}\text { Analiza cech strukturalnych } \\
\text { teksu naukowego }\end{array}$ & $\begin{array}{l}\text { Zachowania informacyjne } \\
\text { naukowców }\end{array}$ \\
\hline Organizacja wiedzy & $\begin{array}{l}\text { Uniwersalne metody } \\
\text { organizacji wiedzy }\end{array}$ & $\begin{array}{l}\text { Analiza domen wiedzy } \\
\text { „Users' warrant' }\end{array}$ \\
\hline
\end{tabular}

Uznając wewnętrzną niespójność, różnorodność i multidyscyplinarność za cechy specyficzne dla pola badań informatologicznych, już w latach 70. w nazewnictwie anglojęzycznym zaczęto upowszechniać nazwę Information Studies (studia informacyjne), a nieco później Information Research (badania informacyjne). Polski odpowiednik „studia informacyjne”, sygnalizujący heterogeniczny charakter interdyscyplinarnego pola badawczego nauki o informacji, w połowie lat 90. xx w. bezskutecznie próbowano włączyć do nazwy instytutu prowadzącego studia biblioteczno-informacyjne na Uniwersytecie Warszawskim. Miała ona przyjąć formę „Instytut Studiów Informacyjnych i Bibliologii”, jednak brak zrozumienia sensu tego określenia i kompetencyjne sporty między wydziałami doprowadziły ostatecznie do zatwierdzenia przez senat uczelni dość dziwnie brzmiącej obecnej nazwy: „Instytut Informacji Naukowej i Studiów Bibliologicznych”. Zamiast informacji naukowej to bibliologia otrzymała więc nieoczekiwanie - i raczej niesłusznie - etykietę eklektycznego i wewnętrznie niespójnego obszaru interdyscyplinarnych badań.

Blaise Cronin twierdzi, że określenie „studia informacyjne” stanowi wygodną, ale niezbyt jasną kontaminację, obejmującą konfigurację różnorodnych i często luźno ze sobą powiązanych badań, dotyczących zjawiska informacji oraz procesów informacyjnych i komunikacyjnych ujmowanych z różnych perspektyw analizowania i w różnych aspektach 
organizowania transmisji wiedzy w świecie człowieka (Cronin, 2012). Takie podejście do nauki o informacji jest dziś szeroko stosowane na świecie, zwłaszcza w odniesieniu do fenomenologicznego nurtu badań ukierunkowanych na poznawanie czynników warunkujących zachowania informacyjne, organizowanie wiedzy i wykorzystywanie jej. Podejście to uwidacznia też pewne problemy dyscypliny, które warto tu zasygnalizować: fragmentaryczność poznania, niski stopień kumulatywnego narastania wiedzy o badanych problemach, niewielki odsetek dtugotrwatych programów badawczych, nikłe znaczenie wyników badań dla praktyki informacyjnej, słaby związek między badaniami naukowymi i działalnością praktyczną.

Część badaczy łączy używanie ogólniejszej nazwy Information Studies w zastępstwie Information Science z potrzebą podkreślenia, że jest to multidyscyplinarna nauka społeczna, a nie nauka ścisła, co w języku angielskim tradycyjnie konotuje wyraz science. W tym kontekście warto zwrócić uwagę na postęp, jaki dokonał się w ostatnich dwóch - trzech dekadach w metodologii badawczej dyscypliny, która z nauki ukierunkowanej początkowo praktycznie i związanej z poszukiwaniem przede wszystkim zastosowań dla nowoczesnych technologii w organizacji i realizacji procesów informacyjnych, wyraźnie przekształca się w dyscyplinę akademicką, rozwijającą teoretyczne i epistemologiczne podstawy prowadzonych w niej dociekań. W szczególności intensywne poszukiwania teoretycznych podstaw badań informacyjnych charakteryzują nurt fenomenologiczny, ukierunkowany na poznanie fenomenu informacji w świecie społecznym.

W połowie lat 70. $\mathrm{xx}$ w. jako nazwy dyscypliny zaczęto też używać przejętej z nauk o zarządzaniu nazwy Information Management, ogólnie oznaczającej działalność polegającą na tworzeniu kolekcji różnego typu informacji pochodzących z jednego lub wielu źródeł i ich dystrybucji w określonym środowisku użytkowników, najczęściej związanych z pewną organizacją lub instytucją. Zarządzanie oznacza tu organizację i kontrolę zasobów informacyjnych, ich przetwarzanie i dostarczanie do określonych jednostek lub grup odbiorców. Od połowy lat 90. xx w. wraz z rosnącym zainteresowaniem informacją biznesową i działalnością informacyjną w różnego rodzaju organizacjach popularność nazwy Information Management w nauce o informacji zaczęła również gwałtownie rosnąć i z czasem stała się jedną z najczęściej używanych etykiet całej dyscypliny, stosowaną w nazwach wielu wydziałów uniwersyteckich kształcących specjalistów informacji (Webber, 2003; Hjørland, 2011). Badania bibliometryczne wykazują też wyraźne nasilanie się interdyscyplinarnych powiązań między nauką o informacji i naukami o zarządzaniu (Larivière et al., 2012, s. 1005). W połowie lat 90., także za naukami o zarządzaniu, stosować zaczęto nazwę Knowledge Management, która wyraża - mówiąc najogólniej - przesunięcie uwagi z organizowania i dystrybucji zasobów informacyjnych za pomocą technologii komputerowych na wspieraną nowoczesnymi technologiami informacyjnymi i komunikacyjnymi organizację transferu wiedzy między ludźmi. W nauce o informacji szczególnie upowszechniło się stosowanie określenia łączącego obie te nazwy - Zarzadzanie informacja $i$ wiedza (Information and Knowledge Management) - jako najlepiej odwzorowujące zakres problemów podejmowanych w informatologii (por. Świgoń, 2012).

Wśród informatologów coraz więcej zwolenników ma również przekonanie, że to nie informacji lecz właśnie ludzkiej wiedzy i pośrednictwa w jej transferze dotyczą badania informatologiczne. Wiedza traktowana była jako centralny przedmiot badań we wczesnych okresach rozwoju dyscypliny, zwłaszcza w jej Otletowskim ujęciu. Skupienie uwagi na 
komputerowym przetwarzaniu informacji od lat 40. do 70. xx w. wyraźnie na plan pierwszy wysunęło kategorię informacji, jednak już w latach 80. ponownie wiedza zaczęła być lokowana w centrum zainteresowań badawczych informatlogów. Wykazało to m.in. krytyczne studium delfickie przeprowadzone w latach 2003-2005 przez Chaima Zinsa wśród kilkudziesięciu najbardziej znanych badaczy dyscypliny, pochodzących z 16 krajów (Zins, 2006, 2007a, 2007b). Zdecydowana większość uczestników tych badań właśnie wiedzę wskazała jako główną kategorię badawczą współczesnej nauki o informacji. Co ciekawe okazało się też, że większość tych uznanych na świecie specjalistów Information Science skłonna byłaby zaakceptować zmianę jej nazwy na Knowledge Science (Zins, 2006, s. 145).

Wynikiem badań Zinsa była też identyfikacja aż sześciu różnych modeli nauki o informacji (tabela 3). Każdy z nich wiąże się z innym korpusem wiedzy, a więc i różnymi polami badawczymi. Spośród tych sześciu modeli za najbardziej reprezentatywne dla postrzegania celów badawczych współczesnej nauki o informacji uznać należy cztery pierwsze: (1) model dyscypliny jako obszaru badań zjawisk informacyjnych w systemach komputerowych (Hi-Tech), (2) model dyscypliny jako obszaru badań zjawisk informacyjnych w kulturze (kulturowy, społeczny), (3) model dyscypliny jako obszaru badań zjawisk informacyjnych związanych z człowiekiem (model świata człowieka), (4) model dyscypliny jako obszaru badań zjawisk informacyjnych w świecie biologicznym (organizmów żywych). W różnych konfiguracjach kompleks zjawisk informacyjnych "dane - informacja - wiedza - komunikat” ujmowany jest z punktu widzenia człowieka wykorzystującego te zjawiska i/lub technologii ułatwiającej ich wykorzystywanie. Zdecydowana większość ekspertów uczestniczących w badaniach reprezentowała jednak model kulturowy, stąd Zins uznał, że uprawianie nauki o informacji jako nauki społecznej zajmującej się zjawiskami kulturowymi stanowi współcześnie jej główny nurt.

Tabela 3. Sześć koncepcji nauki o informacji wyodrębnionych przez Ch. Zinsa (przekład na podstawie: Zins, 2006, s. 144).

\begin{tabular}{|c|c|c|c|c|c|}
\hline \multirow{2}{*}{ ZAKRES } & \multirow{2}{*}{ DOMENA } & \multicolumn{4}{|c|}{ BADANE PRZEDMIOTY: ZJAWISKA INFORMACYJNE } \\
\hline & & DANE & INFORMACJA & WIEDZA & KOMUNIKATY \\
\hline \multirow{3}{*}{ 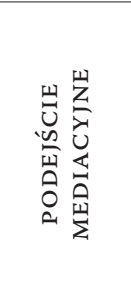 } & Model 1: Hi-Tech & \multicolumn{4}{|c|}{$\begin{array}{l}\text { Mediacyjne aspekty transmisji D-I-W-K } \\
\text { w systemach komputerowych }\end{array}$} \\
\hline & Model 2: Technologia & \multicolumn{4}{|c|}{$\begin{array}{l}\text { Mediacyjne aspekty transmisji D-I-W-K } \\
\text { we wszelkiego typu systemach } \\
\text { (za pomocą wszelkich technologii) }\end{array}$} \\
\hline & $\begin{array}{l}\text { Model 3: Kultura/ } \\
\text { Społeczeństwo }\end{array}$ & \multicolumn{4}{|c|}{$\begin{array}{l}\text { Mediacyjne aspekty transmisji D-I-W-K } \\
\text { w społeczeństwie (między ludźmi) }\end{array}$} \\
\hline \multirow{3}{*}{ 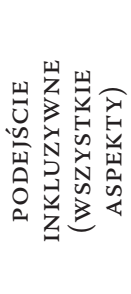 } & Model 4: Świat człowieka & \multicolumn{4}{|c|}{$\begin{array}{l}\text { Wszelkie aspekty D-I-W-K } \\
\text { związane z człowiekiem }\end{array}$} \\
\hline & $\begin{array}{l}\text { Model 5: Świat biologiczny } \\
\text { (organizmów żywych) }\end{array}$ & \multicolumn{4}{|c|}{$\begin{array}{l}\text { Wszelkie aspekty D-I-W-K } \\
\text { związane z organizmami żywymi }\end{array}$} \\
\hline & $\begin{array}{l}\text { Model 6: Świat fizyczny } \\
\text { (organizmów żywych } \\
\text { i zjawisk fizycznych) }\end{array}$ & \multicolumn{4}{|c|}{$\begin{array}{l}\text { Wszelkie aspekty D-I-W-K } \\
\text { związane ze wszystkimi organizmami żywymi } \\
\text { oraz wszelkiego typu obiektami fizycznymi }\end{array}$} \\
\hline
\end{tabular}


Ten pobieżny przegląd najbardziej znanych prób konceptualizacji i rekonceptualizacji nauki o informacji zakończę krótkim omówieniem propozycji Marcii Bates, redaktorki najnowszej, trzeciej edycji Encyclopedia of Library and Information Sciences (ELIS, 2009). Według koncepcji rozwijanej przez Bates od co najmniej kilkunastu lat, nauka o informacji ma charakter specjalnego rodzaju metanauki, która prowadzi badania i buduje teorie dotyczące dokumentacji wiedzy tworzonej przez inne dyscypliny nauki i dziedziny działalności praktycznej, a jej celem jest wyznaczenie optymalnych zasad reprezentowania tej wiedzy i organizowania do niej dostępu. Cechą odróżniającą specjalistów informacji od specjalistów innych dziedzin jest według Bates

(...) myślenie o zasobach [wiedzy] w kategoriach ich własności, które wiaża się z ich organizowaniem i wyszukiwaniem raczej niż $w$ doskonaleniem ich treści” (Bates, 1999 s. 1046) ${ }^{10}$.

Pole badawcze nauki o informacji Bates opisuje następująco:

Nauka o informacji ma odrębne uniwersum, które bada - świat zapisanej informacji wytworzonej przez człowieka. Możemy wyobrazić sobie wszystkie działania człowieka podejmowane w badaniu świata natury, świata społecznego, świata sztuki jako prowadzace do tworzenia jednostek informacyjnych - książek, artykułów, baz danych, plików komputerowych, etc. - a zatem do tworzenia czwartego uniwersum, uniwersum utrwalonej informacji. (...) Poza zapisem wyników badań naukowych, uniwersum utrwalonej informacji zawiera wiele innych rodzajów informacjiliterature popularna, dokumentację biznesowa, archiwa osobowe, muzyke, filmy, etc. i oczywiście wszystko to również $w$ formacie elektronicznym. W skrócie, dokumentacyjne produkty ludzkiej działalności tworza uniwersum wymagajace badania, i badanie tego uniwersum - a także ludzi będących jego twórcami, przeszukujących je, wyszukujących w nim i wykorzystujących je - stanowi intelektualnq domenę nauki o informacji (Bates, 1999, s. 1048) ${ }^{11}$.

Myślenie o nauce o informacji jako swoistej metanauce, nauce o nauce czy nauce wspierającej rozwój nauki, nie jest nowe. Można by tu przypomnieć wspomniany już wcześniej sposób rozumienia informacji naukowej przez M. Dembowską - jako jednej z dziedzin organizacji nauki (Dembowska, 1965, s. 55). Z kolei „czwarte uniwersum utrwalonej informacji” przywodzi na myśl Popperowski „trzeci świat”, do którego już wcześniej odwoływał się Bertram Brooks (1980). W koncepcji Bates jednak na tę informacyjną metanaukę składa się dość liczne i luźno powiązane (przynajmniej dotychczas) spektrum „i-dyscyplin”, dyscyplin informacyjnych, dla których wspólne jest ogniskowanie uwagi na utrwalonej informacji o poznawanych przez człowieka elementach świata natury i artefaktach o znaczeniu kulturowym. Tak więc, spektrum to współtworzą z jednej strony dyscypliny skupione na

10 (...) to think about a resource in terms of the features that matter to the organization and retrieval of it, rather than in terms of mastering its content.

11 Information science has a distinct universe that it studies also-the world of recorded information produced by human agency. We can imagine all the human activities in studying the above natural, social, and artistic universes themselves producing information entities-books, articles, databases, data files, etc.-thus creating a fourth universe, that of recorded information. (...) The recorded information universe contains many other kinds of information besides research results-popular literature, business records, personal archives, music, film, etc., and, of course, all of these in electronic form as well. In short, the documentary products of human activity themselves form a universe deserving of study, and study of that universe-and how human beings produce it, seek it, retrieve it, and use it-is the intellectual domain of information science. 
zapisie kulturowym (Disciplines of the Cultural Record), a z drugiej różne nauki o informacji skupione na potrzebach oraz metodach i środkach (mediach, procesach, narzędziach) organizowania dostępu do ludzkiej wiedzy (The Sciences of Information). Główne problemy badawcze tego złożonego obszaru dociekań wyznacza poszukiwanie odpowiedzi na trzy ogólnie sformułowane pytania: (1) O aspekt fizyczny: Jakie są własności i prawa rządzące uniwersum utrwalonej informacji? (2) O aspekt społeczny: Jak ludzie są powiązani z tym uniwersum, jak je przeszukują i wykorzystują? (3) Techniczne, optymalizacyjne: Jak można zapewnić możliwie najszybszy i najbardziej efektywny dostęp do utrwalonej wiedzy?

Specyficzna dla nauki o informacji multidyscyplinarność, która potęguje się wraz z upowszechnieniem technologii informacyjnych i rozwojem usług informacyjnych w różnych obszarach życia, bez wątpienia wpływa na poszerzanie się i różnicowanie jej pola badawczego. Zjawisko to może wywoływać wrażenie dezintegracji dyscypliny, zwłaszcza że problematyka komunikowania informacji i wiedzy oraz wykorzystywania w tym celu nowoczesnej technologii komputerowej znajduje się obecnie w polu badań różnych nauk. Trzeba jednak przypomnieć za przywoływanym już Karlem Popperem, że o odrębności dyscyplin naukowych nie decyduje przedmiot badań, lecz rodzaj podejmowanych w nich problemów naukowych (Popper, 1999). W nauce o informacji głównym problemem, którego rozwiązaniu służą prowadzone badania jest zapewnienie skutecznego, czyli szybkiego i adekwatnego do potrzeb, komunikowania utrwalonej wiedzy pomiędzy ludźmi w różnych środowiskach ich aktywności przy użyciu możliwie najbardziej efektywnych narzędzi technicznych. A zatem, w różnych kontekstach społecznych, organizacyjnych i technologicznych, nauka o informacji rozwiązuje problem opanowania i optymalnego skanalizowania rosnących strumieni informacji i wiedzy, które winy zasilać badania naukowe i racjonalne decyzje w różnych sferach życia społecznego, a także działań jednostek. Niezależnie od następującego z czasem rozszerzenia pola badawczego nauki o informacji od początkowego skupiania uwagi na szeroko, za Otletem, rozumianym dokumencie do obecnie obejmowania badaniami różnych form przekazu w pewien sposób utrwalonych treści, od początkowo komunikacji głównie treści związanych z działalnością naukową do obecnie wszelkiego rodzaju informacji niezbędnych ludziom w różnych obszarach życia, od początkowo skupiania uwagi przede wszystkim na rozwiązaniach praktycznych do pogłębionej analizy różnorodnych czynników wpływających na poszukiwanie przez ludzi informacji i wykorzystywanie pozyskanej wiedzy - ten główny problem naukowy pozostaje niezmienny i bez wątpienia daleko jeszcze do jego rozwiązania.

\section{Nurty badawcze we współczesnej nauce o informacji w świetle najnowszych publikacji w najważniejszych międzynarodowych czasopismach}

Analiza zawartości najnowszych roczników czasopism z zakresu nauki o informacji pozwoli skonfrontować przestawione wyżej konstatacje o zakresie i specyfice pola badawczego dyscypliny z dokładniejszym obrazem badań prowadzonych w niej obecnie. Tego rodzaju analizy na podstawie różnych rodzajów źródeł są dość często przeprowadzane zarówno przez polskich (np. Pindlowa i Krakowska 2002; Sosińska-Kalata, 2007; Janiak 2010) jak i zagranicznych autorów (np. Aharony, 2011; Larivière et al., 2012). Wybór kryteriów 
identyfikacji piśmiennictwa poddawanego analizie, czy też jego reprezentatywnej próby, decyduje o tym na ile wiarygodne i kompletne są uzyskane ustalenia. Ze względu na to, że w nauce o informacji czasopisma pełnią rolę głównego medium transferu wiedzy o najnowszych badaniach, najczęściej poddaje się analizie zawartość właśnie periodyków uznawanych za najważniejsze dla dyscypliny. Oznacza to zwykle wybór czasopism międzynarodowych zarejestrowanych w "Journal Citation Reports” w kategorii Information and Library Science (I\&LS). Wybór badanego piśmiennictwa bywa też opierany na przeszukiwaniu abstraktowych baz bibliograficznych za pomocą terminów reprezentujących główne kategorie badawcze dyscypliny. W przypadku nauki o informacji najczęściej jest to jedno z dwóch takich źródeł: Library and Information Science Abstracts (LISA) lub Library, Information Science and Technology Abstracts (LISTA). Niekiedy analizie poddaje się też tematykę dysertacji z zakresu badanej dyscypliny albo tematykę materiałów konferencyjnych publikowanych przez organizatorów najważniejszych konferencji uznawanych w środowisku dyscypliny za dla niej reprezentatywne. W badaniach zmierzających do osiągnięcia możliwie wysokiego poziomu kompletności analizowanych danych wykorzystuje się równocześnie wiele różnych źródeł bibliograficznych i katalogów bibliotecznych, jak np. w badaniach dotyczących informacji naukowej w Polsce, przeprowadzonych przez Małgorzatę Janiak (2010). Analizy dążące do wszechstronnego ujęcia pola badawczego dyscypliny bywają również opierane na przeglądzie programów związanych z nią ośrodków badawczych, prac zatrudnionych w nich badaczy i eksperckim wyborze piśmiennictwa, obejmującym różnego rodzaju formy piśmiennicze - taki charakter miały np. badania Marii Dembowskiej, przedstawione w książce Nauka o informacji naukowej (informatologia). Organizacja i problematyka badań w Polsce (1991).

Rozproszenie piśmiennictwa naukowego i ograniczenia subiektywnych wyborów i ocen powodują, że żadna ze wskazanych wyżej metod nie zapewnia całościowego wglądu w problematykę badań podejmowanych w nauce o informacji, choć oparte na nich analizy dostarczają wartościowych informacji o kształtujących się tendencjach i ewolucji zainteresowań. Różne podejścia poszczególnych badaczy do określenia celów poznawczych nauki o informacji dodatkowo utrudniają porównywanie uzyskanych przez nich wyników. Ze świadomością zatem ograniczeń tego typu ocen, w niniejszej części artykułu przedstawione są wyniki analizy kierunków badań w nauce o informacji uprawianych na świecie, przeprowadzonej na niedużym zbiorze 301 artykułów opublikowanych w latach 2011 i 2012 w trzech czasopismach międzynarodowych o najwyższym wskaźniku wpływu na rozwój nauki oraz 60 artykułów składających się na pięć ostatnich roczników „Annual Review of Information Science and Technology" (2007-2011).

Spośród czasopism zarejestrowanych w Web of Science, do kategorii Information and Library Science w 2011 r. zaliczono 83 tytuły. Warto zauważyć, że w ciągu ostatnich 8 lat w grupie tej nastąpił wzrost liczby rejestrowanych tytułów o ponad $50 \%$, co ma oczywisty związek z generalnym wzrostem zainteresowania badaniami dotyczącymi technologii informacyjnych i ich społecznego użytkowania (zob. rys. 1).

Niejednoznaczna interpretacja zakresu kategorii I\&LS, a w szczególności jej członu „Information Science" powoduje jednak, że znaczną część czasopism zakwalifikowanych do kategorii I\&LS stanowią periodyki o wyraźnym ukierunkowaniu informatycznym, czasopisma związane z naukami o zarządzaniu oraz coraz liczniejsze czasopisma specjalizujące się w problematyce zastosowań komputerowej technologii informacyjnej w różnych obszarach 
życia społecznego i badań naukowych. Wśród pierwszych 20 tytułów o najwyższym Impact Factor (IF) w tej kategorii ponad połowę (11) stanowią czasopisma informatyczne i menadżerskie. Trzeba też zwrócić uwagę na pogłębiającą się specjalizację w grupie czasopism zajmujących się różnymi dyscyplinami informacyjnymi.

Rys. 1. Wykres liniowy wzrostu liczby czasopism w kategorii I\&LS w latach 2004-2011

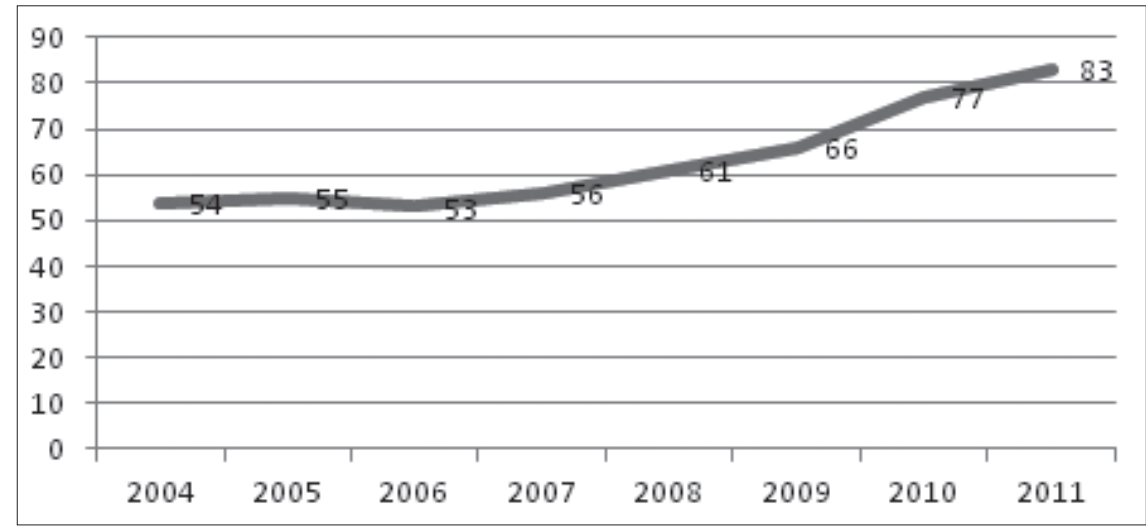

Wśród tytułów o najwyższym IF w analizowanej kategorii znajdują się dwa czasopisma poświęcone ilościowym badaniom nauki i piśmiennictwa naukowego („Journal of Informetrics”, IF = 4.229; „SCientometrics”, IF = 1.966). Ciekawym zjawiskiem jest szybki awans „Journal of Informetrics”, redagowanego przez Leo Egghe kwartalnika informetrycznego, który ukazuje się zaledwie od 2007 r., do grupy czasopism o najwyższym współczynniku wpływu w kategorii Information and Library Science. Obecnie jest on drugim tytułem pod względem wysokości If. Wskaźnik wpływu tego czasopisma jest zdecydowanie najwyższy wśród czasopism informatologicznych, a w ostatnich 5 latach widoczny jest jego systematyczny wzrost, lekko wyhamowany jedynie w 2010 r. (5-letni IF $=3.944$; w kolejnych latach: $2008-$ IF $=2.531 ; 2009-$ IF $=3.379 ; 2010-$ IF $=3.119 ; 2011-$ IF $=4.229)$. Wartość IF „Journal of Informetrics” jest zdecydowanie wyższa niż wartość współczynnika wpływu ARIS\&T (IF = 2.955) i JASIST (IF = 2.081) - dwóch najczęściej cytowanych czasopism o ogólnie zdefiniowanym informatologicznym profilu tematycznym.

Wśród tytułów o wysokich wskaźnikach cytowalności znacząca jest też liczba czasopism poświęconych problematyce informacji w różnych dziedzinach, w szczególności informacji medycznej i nauk o zdrowiu, a także informacji prawniczej i administracyjnej oraz informacji geograficznej. Wreszcie, pewną część czasopism zakwalifikowanych do analizowanej kategorii stanowią tytuły interdyscyplinarne, na łamach których przedstawiane są badania dotyczące różnych aspektów technologii informacyjnej i jej społecznego wykorzystywania w różnych obszarach życia (np. „Information Society”, „Information Technology and People”, „Social Science Computer Review”).

Spośród tej zróżnicowanej grupy czasopism do sondowania tendencji w kształtowaniu problematyki badawczej współczesnej nauki o informacji na świecie dla potrzeb niniejszego artykułu wybrałam cztery czasopisma o ogólnie zdefiniowanym informatologicznym profilu tematycznym i najwyższym wskaźniku wpływu w tej grupie:

„Annual Review of Information Science and Technology" (ARIS\&T) - IF = 2.955 
„Journal of the American Society for Information Science and Technology” (JASIST) $\mathrm{IF}=2.081$

„Journal of Information Science” (JIS) - IF = 1.299

„Journal of Documentation” (JDoc) - IF = 1.058)

Ze względu na zróżnicowaną częstotliwość publikowania tych czasopism, różna jest liczba prac ukazujących się na ich łamach. JASIs T jest miesięcznikiem, w którego każdym numerze ukazuje się ostatnio po 12-14 artykułów, a zatem w ciągu roku na jego łamach publikowanych jest ponad 144 artykułów. JIS i JDoc są dwumiesięcznikami, których każdy zeszyt zawiera 7-9 artykułów. W każdym z tych czasopismach rocznie ukazuje się zatem po około 40 tekstów. Zadaniem rocznika ARIS\&T jest systematyczne monitorowanie bieżących trendów badawczych i omawianie obszarów badań, w których w ostatnich latach dokonane zostały najbardziej znaczące osiągnięcia. Każdy tom zawiera około 9-10 obszernych artykułów przeglądowych, w których omawiane jest zwykle kilkadziesiąt prac reprezentujących dane pole badawcze. Aby uchwycić rozkład tematyki badań prowadzonych w ostatnim czasie w nauce o informacji i uniknąć deformacji jego obrazu implikowanej przez różną liczebność tekstów publikowanych na łamach poszczególnych czasopism i stosowaną w nich politykę redakcyjną, przeprowadzona analiza objęła tylko jeden, ostatni rocznik JASIST (dostępne w momencie przeprowadzania badań numery 1-10 z 2012 roku, w których łącznie opublikowano 145 artykułów), po dwa roczniki JIs i JDoc (2011 i 2012 rok, w których łącznie w pierwszym czasopiśmie opublikowano 83 artykuły, a w drugim 73) oraz pięć roczników ARIS\&T (łącznie 60 artykułów). Z uwagi na specyfikę rocznika ARIS\&T wyniki analizy jego zawartości porównywane są z danymi obrazującymi rozkład poszczególnych pól tematycznych we wszystkich trzech pozostałych czasopismach.

Wyodrębnianie pól tematycznych, reprezentowanych przez badania omawiane na łamach badanych czasopism zostało oparte na wieloaspektowej analizie treści artykułów. Pod uwage brana była zarówno dziedzina zastosowania przedstawianych systemów, usług, serwisów, identyfikowanych potrzeb informacyjnych, jak i rodzaj analizowanych zjawisk, obiektów czy procesów. W rezultacie większość artykułów zakwalifikowana została do dwóch lub więcej obszarów tematycznych, a zatem odsetki tekstów poświęconych poszczególnym zagadnieniom nie sumują się do 100 . Taki sposób charakteryzowania problematyki badawczej prezentowanej w artykułach dobrze jednak oddaje jej multidyscyplinarność i pozwala na dokładniejszy wgląd w poszczególne nurty badawcze. Ostatecznie wyodrębnionych zostało 26 względnie ogólnie określonych obszarów badań, spośród których 7 szczególnie intensywnie eksplorowanych podzielone zostało na bardziej szczegółowe klasy tematyczne. Wyniki analizy prezentuje tabela 4.

Uzyskane dane potwierdzają jednoznacznie, iż główne i najintensywniej eksplorowane nurty badawcze we współczesnej nauce o informacji stanowią nadal zagadnienia związane z jednej strony z rozwojem technologii informacyjnych, a z drugiej z badaniem użytkowników i użytkowania informacji.

Problematyce technologii informacyjnej, jej projektowaniu i testowaniu różnych metod komputerowego przetwarzania informacji w badanych rocznikach JASIST, JIS i JDoc łącznie poświęconych było blisko 38\% artykułów, a w ostatnich pięciu latach w ARIS\&T poświęcono im aż 35\% opublikowanych tam przeglądów. W tym nurcie badań obecnie nadal najwięcej uwagi poświęca się doskonaleniu metod wyszukiwania informacji $(9,64 \%$ artykułów w trzech badanych czasopismach i 6,67\% przeglądów w ARIST). Dwa kolejne 
najintensywniej eksplorowane obszary stanowią data mining, text mining i Web mining (6,98\% artykułów w badanych czasopismach i 5\% przeglądów w ARIST) oraz metody NLP - automatycznego przetwarzania języka naturalnego, automatycznego indeksowania tekstów (w szczególności w językach nie-europejskich), automatycznej klasyfikacji tekstów (6.64\% w trzech analizowanych czasopismach i 5\% przeglądów w ARIST). Bardzo wyraźnie widoczne jest też zdecydowanie większe zainteresowanie tą problematyką w bardziej technologicznie ukierunkowanych JASIST (43,45\%) i JIS $(56,62 \%)$, niż w „Journal of Documentation" (5,48\%), którego profil wiąże się silniej z problematyką badań społecznych $\mathrm{w}$ informatologii.

Tabela 4. Obszary badań w nauce o informacji na podstawie analizy czasopism międzynarodowych

\begin{tabular}{|c|c|c|c|c|c|c|c|c|c|c|c|}
\hline \multirow[t]{2}{*}{ L.P. } & \multirow[t]{2}{*}{ OBSZAR BADAŃ } & \multicolumn{2}{|c|}{ 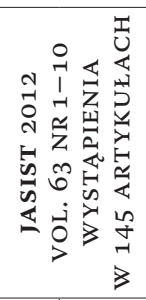 } & \multicolumn{2}{|c|}{ 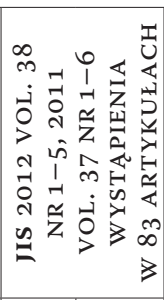 } & \multicolumn{2}{|c|}{ 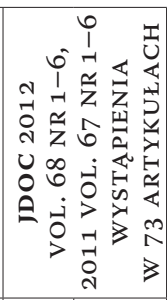 } & \multicolumn{2}{|c|}{ 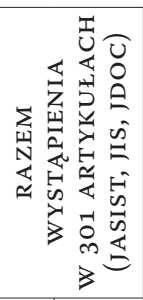 } & \multicolumn{2}{|c|}{ 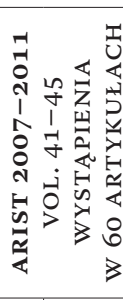 } \\
\hline & & 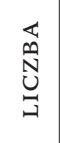 & $\begin{array}{l}\text { 光 } \\
\stackrel{\text { 㟧 }}{0} \\
0\end{array}$ & 总 & 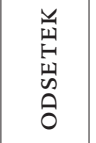 & 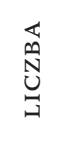 & 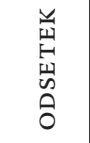 & 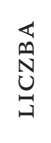 & 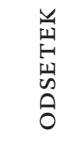 & 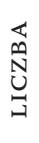 & 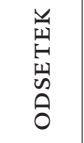 \\
\hline 1 & ANALIZA DOMEN WIEDZY & 10 & 6.90 & - & - & - & - & 10 & 3.32 & 6 & 10.00 \\
\hline 1 & $\begin{array}{l}\text { Informacja chemiczna, chemio- } \\
\text { informatyka }\end{array}$ & & & & & & - & & & 1 & 1.67 \\
\hline 2 & Informacja edukacyjna & & & & & & - & & & 1 & 1.67 \\
\hline 3 & Informacja farmaceutyczna & & & & & & - & & & 1 & 1.67 \\
\hline 4 & $\begin{array}{l}\text { Informacja geograficzna, geoin- } \\
\text { formatyka }\end{array}$ & & & & & & - & & & 1 & 1.67 \\
\hline 5 & Informacja o zdrowiu & 3 & 2.07 & - & - & 1 & 1.37 & 4 & 1.33 & 1 & 1.67 \\
\hline 6 & Informacja biomedyczna & 1 & 0.69 & - & - & & - & 1 & 0.33 & - & 1.67 \\
\hline 7 & Informacja patentowa & 2 & 1.38 & - & - & & - & 2 & 0.66 & - & - \\
\hline 8 & Informacja prawna & - & - & - & - & 2 & 2.78 & 2 & 0.66 & - & - \\
\hline 9 & Informacja publiczna & & & & & & - & & & 1 & 1.67 \\
\hline 10 & $\begin{array}{l}\text { Informacja społeczna, informaty- } \\
\text { ka społeczna }\end{array}$ & 2 & 1.38 & - & - & 1 & 1.37 & 3 & 1.00 & - & - \\
\hline 11 & Informacja medyczna & 2 & 1.38 & - & - & - & - & 2 & 0.66 & - & - \\
\hline 2 & $\begin{array}{l}\text { Architektura informacji, usa- } \\
\text { bility, projektowanie i ocena } \\
\text { serwisów ww w }\end{array}$ & - & - & 1 & 1.20 & - & - & 1 & 0.33 & 1 & 1.67 \\
\hline 3 & $\begin{array}{l}\text { Archiwa cyfrowe, biblioteki } \\
\text { cyfrowe, repozytoria cyfrowe }\end{array}$ & 1 & 0.69 & 2 & 2.41 & 2 & 2.78 & 5 & 1.66 & 1 & 1.67 \\
\hline 4 & BADANIA UŻYTKOWNIKÓw & 35 & 24.14 & 13 & 15.66 & 21 & 28.77 & 68 & 22.59 & 11 & 18.3 \\
\hline
\end{tabular}




\begin{tabular}{|c|c|c|c|c|c|c|c|c|c|c|c|}
\hline \multirow[t]{2}{*}{ L.P. } & \multirow[t]{2}{*}{ OBSZAR BADAŃ } & \multicolumn{2}{|c|}{ 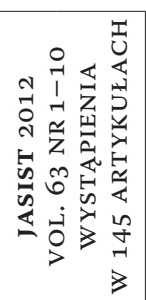 } & \multicolumn{2}{|c|}{ 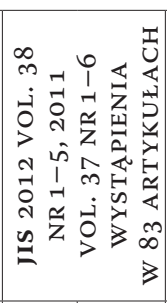 } & \multicolumn{2}{|c|}{ 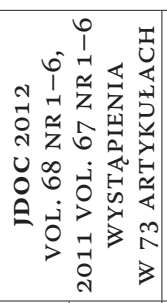 } & \multicolumn{2}{|c|}{ 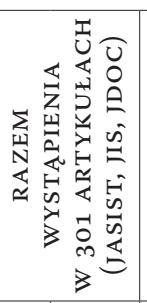 } & \multicolumn{2}{|c|}{ 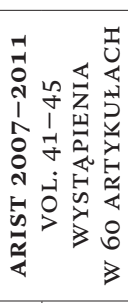 } \\
\hline & & 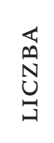 & $\begin{array}{l}\stackrel{y}{\mu} \\
\text { 岃 } \\
\text { 命 } \\
0\end{array}$ & 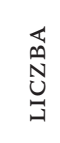 & $\begin{array}{l}\text { 嵒 } \\
\text { 岀 } \\
\text { 今 } \\
0\end{array}$ & 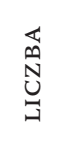 & $\begin{array}{l}\text { 嵒 } \\
\text { 岀 } \\
\text { 今 } \\
0\end{array}$ & 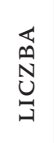 & 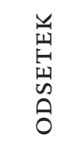 & 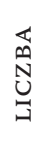 & $\begin{array}{l}\text { 嵒 } \\
\text { 岀 } \\
\text { 号 } \\
0\end{array}$ \\
\hline 1 & $\begin{array}{l}\text { Codzienne zachowania informa- } \\
\text { cyjne }\end{array}$ & 3 & 2.07 & - & - & - & - & 3 & 1.00 & 2 & 3.33 \\
\hline 2 & $\begin{array}{l}\text { Zachowania informacyjne } \\
\text { specjalistów różnych dziedzin, } \\
\text { wyszukiwanie informacji, użyt- } \\
\text { kowanie informacji, wykorzysta- } \\
\text { nie Internetu }\end{array}$ & 30 & 20.69 & 11 & 13.25 & 19 & 20.03 & 65 & 21.59 & 9 & 15.00 \\
\hline 3 & $\begin{array}{l}\text { Kompetencje informacyjne (in- } \\
\text { formation literacy); kompetencje } \\
\text { w zakresie informacji geoprze- } \\
\text { strzennej; kompetencje w zakre- } \\
\text { sie oceny źródeł informacyjnych }\end{array}$ & 2 & 1.38 & 2 & 2.41 & 2 & 2.78 & 6 & 1.99 & - & - \\
\hline 5 & Bariery językowe & 2 & 1.38 & 1 & 1.20 & - & - & 3 & 1.00 & - & - \\
\hline 6 & Bibliologia, historia bibliotek & - & - & - & - & 1 & 1.37 & 1 & 0.33 & - & - \\
\hline 7 & $\begin{array}{l}\text { Bibliologia, społeczna funkcja } \\
\text { książki, dostępność książek } \\
\text { wycofanych z kolekcji biblio- } \\
\text { tecznych }\end{array}$ & - & - & - & - & 1 & 1.37 & 1 & 0.33 & - & - \\
\hline 8 & $\begin{array}{l}\text { BADANIA ILOŚCIOWE WYKO- } \\
\text { RZYSTANIA INFORMACJI }\end{array}$ & 42 & 28.97 & 5 & 6.02 & 4 & 5.48 & 51 & 16.94 & 6 & 10.00 \\
\hline 1 & $\begin{array}{l}\text { Bibliometria, informetria, nauko- } \\
\text { metria }\end{array}$ & 36 & 24.83 & 4 & 4.82 & 3 & 4.11 & 43 & 14.28 & 6 & 10.00 \\
\hline 2 & Webometria & 6 & 4.14 & 1 & 1.20 & 1 & 1.37 & 8 & 2.66 & - & - \\
\hline 9 & $\begin{array}{l}\text { Bibliotekoznawstwo: marketing } \\
\text { biblioteczny, e-booki; ochrona } \\
\text { zbiorów bibliotecznych }\end{array}$ & - & - & - & - & 2 & 2.78 & 2 & 0.66 & - & - \\
\hline 10 & Biblioterapia & - & - & - & - & 1 & 1.37 & 1 & 0.33 & - & - \\
\hline 11 & Dokumentacja archiwalna & - & - & - & - & 1 & 1.37 & 1 & 0.33 & - & - \\
\hline 12 & $\begin{array}{l}\text { Ekonomia informacji; e-gospo- } \\
\text { darka }\end{array}$ & - & - & - & - & - & - & & & 3 & 5.00 \\
\hline 13 & Etyka informacyjna & 1 & 0.69 & - & - & - & - & 1 & 0.33 & - & - \\
\hline 14 & Humanistyka cyfrowa & - & - & - & - & 1 & 1.37 & 1 & 0.33 & - & - \\
\hline 15 & $\begin{array}{l}\text { Komunikacja człowieka z ma- } \\
\text { szyną; HCI teoria }\end{array}$ & - & - & - & - & 1 & 1.37 & 1 & 0.33 & - & - \\
\hline 16 & KOMUNIKACJA NAUKOWA & 19 & 13.10 & 11 & 13.25 & 9 & 12.33 & 39 & 12.96 & 9 & 15.00 \\
\hline
\end{tabular}




\begin{tabular}{|c|c|c|c|c|c|c|c|c|c|c|c|}
\hline \multirow[t]{2}{*}{ L.P. } & \multirow[t]{2}{*}{ OBSZAR BADAŃ } & \multicolumn{2}{|c|}{ 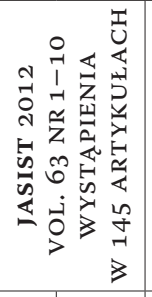 } & \multicolumn{2}{|c|}{ 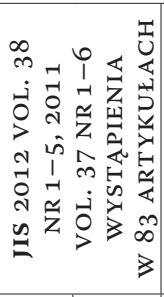 } & \multicolumn{2}{|c|}{ 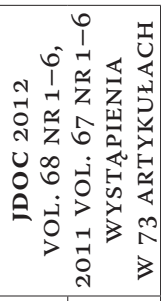 } & \multicolumn{2}{|c|}{ 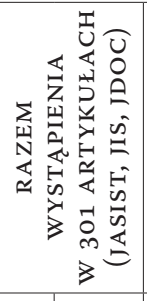 } & \multicolumn{2}{|c|}{ 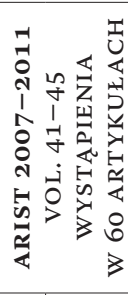 } \\
\hline & & 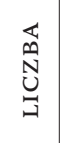 & $\begin{array}{l}\text { 崫 } \\
\text { 岃 } \\
\text { مी } \\
0\end{array}$ & 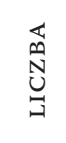 & 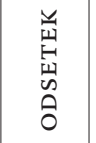 & 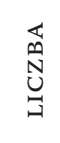 & 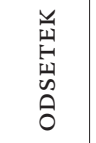 & 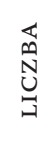 & 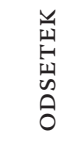 & 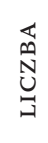 & 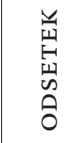 \\
\hline 1 & Komunikacja naukowa & 10 & 6.90 & 3 & 3.61 & 2 & 6.85 & 15 & 4.98 & 5 & 8.33 \\
\hline 2 & $\begin{array}{l}\text { e-Nauka, informatyczna infra- } \\
\text { struktura nauki }\end{array}$ & 3 & 2.07 & 1 & 1.20 & 1 & 1.37 & 5 & 1.66 & 1 & 1.67 \\
\hline 3 & $\begin{array}{l}\text { Open access w komunikacji } \\
\text { naukowej }\end{array}$ & 3 & 2.07 & 3 & 3.61 & 4 & 5.48 & 10 & 3.33 & 2 & 3.33 \\
\hline 4 & $\begin{array}{l}\text { Tekst naukowy (prezentacja } \\
\text { danych, prezentacja wniosków, } \\
\text { formy streszczeń, style cytowań) }\end{array}$ & 3 & 2.07 & 4 & 4.82 & 2 & 2.78 & 9 & 2.99 & 1 & 1.67 \\
\hline 17 & $\begin{array}{l}\text { NAUKA } \\
\text { O INFORMACJI: teoria, pod- } \\
\text { stawowe kategorie badawcze } \\
\text { (dokument, wiedza, informa- } \\
\text { cja), filozofia, epistemologia, } \\
\text { metodologia, historia, eduka- } \\
\text { cja, badania }\end{array}$ & 9 & 6.21 & 4 & 4.82 & 3 & 4.11 & 16 & 5.32 & 14 & 23.33 \\
\hline 18 & Nowe media, media masowe & 3 & 2.07 & - & - & - & - & 3 & 1.00 & - & - \\
\hline 19 & ORGANIZACJA WIEDZY & 17 & 11.72 & 13 & 15.66 & 12 & 16.44 & 44 & 14.62 & 5 & 8.33 \\
\hline 1 & Folksonomie & 4 & 2.76 & 3 & 3.61 & 4 & 5.48 & 11 & 3.65 & 1 & 1.67 \\
\hline 2 & Indeksowanie automatyczne & 2 & 1.38 & - & - & - & - & 2 & 0.66 & - & - \\
\hline 3 & $\begin{array}{l}\text { Indeksowanie informacji gene- } \\
\text { tycznej }\end{array}$ & 1 & 0.69 & - & - & - & - & 1 & 0.33 & - & - \\
\hline 4 & Indeksowanie literatury pięknej & - & - & - & - & 1 & 1.37 & 1 & 0.33 & - & - \\
\hline 5 & $\begin{array}{l}\text { Indeksowanie materiałów ikono- } \\
\text { graficznych, dzieł sztuki }\end{array}$ & 2 & 1.38 & - & - & 3 & 4.11 & 5 & 1.66 & - & - \\
\hline 6 & Klasyfikacja automatyczna & 3 & 2.07 & 5 & 6.02 & - & - & 8 & 2.66 & - & - \\
\hline 7 & Metadane, XML & 2 & 1.38 & 1 & 1.20 & - & - & 3 & 1.00 & 1 & 1.67 \\
\hline 8 & Ontologie & - & - & 4 & 4.82 & - & - & 4 & 1.33 & 1 & 1.67 \\
\hline 9 & Teoria klasyfikacji & 1 & 0.69 & - & - & 4 & 5.48 & 5 & 1.66 & - & - \\
\hline 10 & Teoria ogólna organizacji wiedzy & 2 & 1.38 & - & - & 2 & 2.78 & 4 & 1.33 & 2 & 3.33 \\
\hline 20 & $\begin{array}{l}\text { Polityka informacyjna, podział } \\
\text { cyfrowy, regulacje prawne }\end{array}$ & 2 & 1.38 & 2 & 2.41 & 1 & 1.37 & 5 & 1.66 & 4 & 6.67 \\
\hline 21 & $\begin{array}{l}\text { Polityka naukowa, pozyskiwa- } \\
\text { nie grantów }\end{array}$ & 2 & 1.38 & 1 & 1.20 & - & - & 3 & 1.00 & - & - \\
\hline 22 & SPOŁECZNY WEB & 14 & 9.66 & 9 & 10.84 & 1 & 1.37 & 24 & 7.97 & 5 & 8.33 \\
\hline
\end{tabular}




\begin{tabular}{|c|c|c|c|c|c|c|c|c|c|c|c|}
\hline \multirow[t]{2}{*}{ L.P. } & \multirow[t]{2}{*}{ OBSZAR BADAŃ } & \multicolumn{2}{|c|}{ 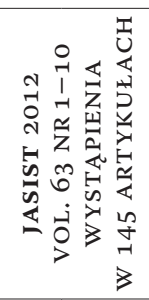 } & \multicolumn{2}{|c|}{ 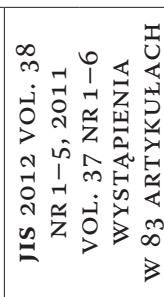 } & \multicolumn{2}{|c|}{ 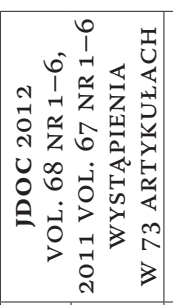 } & \multicolumn{2}{|c|}{ 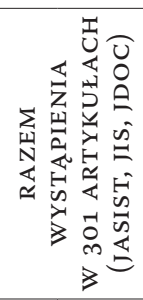 } & \multicolumn{2}{|c|}{ 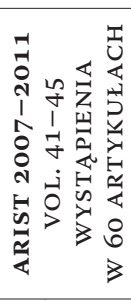 } \\
\hline & & 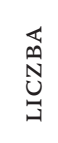 & 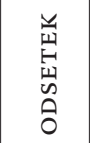 & $\begin{array}{l}\text { 我 } \\
\text { U్త }\end{array}$ & 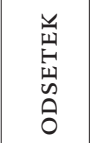 & 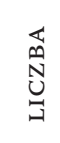 & $\begin{array}{l}\text { 㞾 } \\
\text { 岀 } \\
\text { م̂ }\end{array}$ & 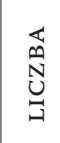 & 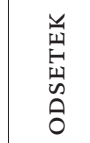 & 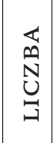 & $\begin{array}{l}\stackrel{y}{山} \\
\text { 岃 } \\
\text { 命 } \\
0\end{array}$ \\
\hline 1 & $\begin{array}{l}\text { Społeczny Web, dzielenie się } \\
\text { wiedzą, społeczne media, ser- } \\
\text { wisy Q\&A, serwisy społecznych } \\
\text { przekładów tekstów }\end{array}$ & 7 & 4.82 & 4 & 4.82 & - & - & 11 & 3.65 & 2 & 3.33 \\
\hline 2 & Społeczny Web, sieci społeczne & 7 & 4.82 & 4 & 4.82 & 1 & 1.37 & 12 & 3.99 & 3 & 5.00 \\
\hline 3 & Społeczny Web, crowdsourcing & - & - & 1 & 1.20 & - & - & 1 & 0.33 & - & - \\
\hline 23 & TECHNOLOGIA INFORMACYJNA & 63 & 43.45 & 47 & 56.62 & 4 & 5.48 & 114 & 37.87 & 21 & 35.00 \\
\hline 1 & Cloud computing & 1 & 0.69 & - & - & - & - & 1 & 0.33 & - & - \\
\hline 2 & $\begin{array}{l}\text { Data mining, text mining, Web } \\
\text { mining (badanie nastrojów, } \\
\text { badanie wątków tematycznych, } \\
\text { analizy sieci społecznych) }\end{array}$ & 14 & 9.66 & 6 & 7.23 & 1 & 1.37 & 21 & 6.98 & 3 & 5.00 \\
\hline 3 & $\begin{array}{l}\text { Detekcja alertów w poczcie elek- } \\
\text { tronicznej }\end{array}$ & - & - & 1 & 1.20 & - & - & 1 & 0.33 & - & - \\
\hline 4 & Detekcja robotów & - & - & 1 & 1.20 & - & - & 1 & 0.33 & - & - \\
\hline 5 & $\begin{array}{l}\text { e-Administracja - narzędzia } \\
\text { informatyczne }\end{array}$ & 1 & 0.69 & - & - & - & - & 1 & 0.33 & 1 & 1.67 \\
\hline 6 & HCI & 6 & 4.14 & - & - & - & - & 6 & 1.99 & 2 & 3.33 \\
\hline 7 & Inżynieria wiedzy & 1 & 0.69 & - & - & - & - & 1 & 0.33 & - & - \\
\hline 8 & Kontrola jakości danych & - & - & 1 & 1.20 & 1 & - & 2 & 0.66 & - & - \\
\hline 9 & $\begin{array}{l}\text { NLP, semantyka, automatyczne } \\
\text { streszczanie, automatycz- } \\
\text { ny przekład, automatyczne } \\
\text { indeksowanie (język arabski, } \\
\text { chiński, turecki), automatyczna } \\
\text { klasyfikacja }\end{array}$ & 11 & 7.59 & 8 & 9.64 & - & - & 20 & 6.64 & 3 & 5.00 \\
\hline 10 & Oprogramowanie bibliometryczne & 1 & 0.69 & 2 & 2.41 & - & - & 3 & 1.00 & - & - \\
\hline 11 & Programy OCR & - & - & 1 & 1.20 & - & - & 1 & 0.33 & - & - \\
\hline 12 & $\begin{array}{l}\text { Technologie semantyczne, Se- } \\
\text { mantyczny Web, ontologie }\end{array}$ & - & - & 8 & 9.64 & - & - & 8 & 2.66 & 2 & 3.33 \\
\hline 13 & Systemy antyplagiatowe & 1 & 0.69 & - & - & - & - & 1 & 0.33 & - & - \\
\hline 14 & Systemy antyspamowe & - & - & 1 & 1.20 & - & - & 1 & 0.33 & - & - \\
\hline 15 & $\begin{array}{l}\text { Systemy automatycznej ekstrak- } \\
\text { cji tematów }\end{array}$ & - & - & 1 & 1.20 & - & - & 1 & 0.33 & - & - \\
\hline
\end{tabular}




\begin{tabular}{|c|c|c|c|c|c|c|c|c|c|c|c|}
\hline \multirow[t]{2}{*}{ L.P. } & \multirow[t]{2}{*}{ OBSZAR BADAŃ } & \multicolumn{2}{|c|}{ 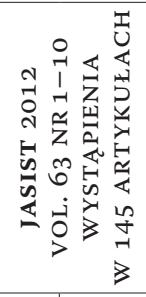 } & \multicolumn{2}{|c|}{ 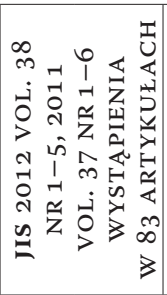 } & \multicolumn{2}{|c|}{ 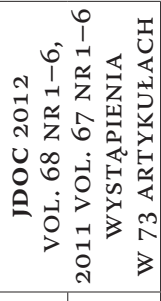 } & \multicolumn{2}{|c|}{ 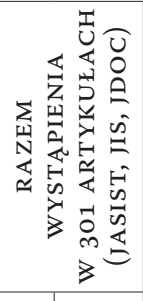 } & \multicolumn{2}{|c|}{ 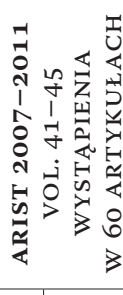 } \\
\hline & & 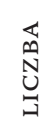 & $\begin{array}{l}\text { 弟 } \\
\text { 岃 } \\
\text { की } \\
0\end{array}$ & 总 & 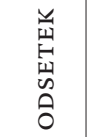 & 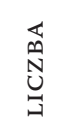 & 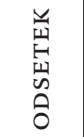 & 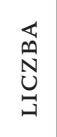 & $\begin{array}{l}\text { 崫 } \\
\text { 岀 } \\
\text { م̂ } \\
0\end{array}$ & 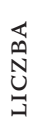 & $\begin{array}{l}\text { 曾 } \\
\text { 㟧 } \\
\text { 。 }\end{array}$ \\
\hline & $\begin{array}{l}\text { Systemy automatycznej identyfi- } \\
\text { kacji autorów }\end{array}$ & 1 & 0.69 & - & - & - & - & & & 1 & 1.67 \\
\hline 16 & $\begin{array}{l}\text { Systemy ekspertowe, sztuczna } \\
\text { inteligencja }\end{array}$ & 1 & 0.69 & - & - & - & - & 1 & 0.33 & 2 & 3.33 \\
\hline & Systemy GIS & & & & & & - & & & 1 & 1.67 \\
\hline 17 & Systemy Q\&A & 2 & 1.38 & 2 & 2.41 & - & - & 4 & 1.33 & - & - \\
\hline 18 & Systemy rekomendacyjne & 1 & 0.69 & 2 & 2.41 & - & - & 3 & 1.00 & - & - \\
\hline 19 & Systemy uczące się & 1 & 0.69 & 4 & 4.82 & - & - & 4 & 1.33 & 1 & 1.67 \\
\hline & Systemy wspierania edukacji & - & - & - & - & - & - & & & 1 & 1.67 \\
\hline 20 & $\begin{array}{l}\text { Teoria algorytmów, algorytmy } \\
\text { genetyczne }\end{array}$ & 1 & 0.69 & - & - & - & - & 1 & 0.33 & - & - \\
\hline 21 & Wizualizacja & 2 & 1.38 & - & - & - & - & 2 & 0.66 & - & - \\
\hline 22 & WYSZUKIWANIE INFORMACJI & 18 & 12.41 & 9 & 10.84 & 2 & 2.78 & 29 & 9.64 & 4 & 6.67 \\
\hline 1 & $\begin{array}{l}\text { Wyszukiwanie informacji - me- } \\
\text { tody, modele, ewaluacja }\end{array}$ & 14 & 9.66 & 6 & 7.23 & 2 & 2.78 & 22 & 7.31 & 4 & 6.67 \\
\hline 2 & $\begin{array}{l}\text { Wyszukiwanie informacji, wy- } \\
\text { szukiwarki internetowe }\end{array}$ & 4 & 2.76 & 1 & 1.20 & - & - & 5 & 1.66 & - & - \\
\hline 3 & Wyszukiwanie informacji, XML & - & - & 2 & 2.41 & - & - & 2 & 0.66 & - & - \\
\hline 24 & $\begin{array}{l}\text { USEUGI INFORMACYJNE: ser- } \\
\text { wisy Q\&A, społeczne serwisy } \\
\text { przekładów, wirtualna rzeczy- } \\
\text { wistość }\end{array}$ & 2 & 1.38 & 3 & 3.61 & 1 & 1.37 & 6 & 1.99 & - & - \\
\hline 25 & $\begin{array}{l}\text { ZARZĄDZANIE INFORMACJA } \\
\text { I WIEDZĄ, komunikacja w biz- } \\
\text { nesie }\end{array}$ & 13 & 8.97 & 6 & 7.23 & 3 & 4.11 & 22 & 7.31 & 7 & 11.67 \\
\hline 26 & $\begin{array}{l}\text { Źródła informacji, wiarygod- } \\
\text { ność informacji, dostępność } \\
\text { informacji }\end{array}$ & - & - & 2 & 2.41 & 1 & 1.37 & 3 & 1.00 & 1 & 1.67 \\
\hline
\end{tabular}

Nurt badań obejmujących analizy zachowań użytkowników oraz ilościowe pomiary wykorzystania informacji w różnych środowiskach (w szczególności naukowym i w www) łącznie w badanej próbie czasopism reprezentuje blisko 40\% artykułów, a wśród przeglądów wydanych w ostatnich pięciu latach w ARIST - ponad 28\% opracowań.

Badań użytkowników, do których zaliczono prace nad zachowaniami i kompetencjami informacyjnymi, dotyczyło 22,59\% artykułów opublikowanych w JASIST, JIS i „Journal of 
Documentation”, przy czym wyraźnie najwięcej publikacji należących do tego obszaru ukazało się na łamach "Journal of Documentation” (28,77\% prac opublikowanych w tym czasopiśmie). Warto jednak zauważyć, że badania użytkowników zajmują też dużo miejsca zarówno w JASIST (dotyczyło ich 24,14\% wszystkich analizowanych artykułów z 2012 roku) jak i w JIS (15,66\% analizowanych artykułów). Kolejną istotną obserwacją jest to, że dużą grupę badań użytkowników stanowią badania związane z oceną użyteczności różnych serwisów i systemów informacyjnych oraz projektowaniem funkcjonalnych interfejsów.

Silny nurt badań we współczesnej nauce o informacji stanowią bez wątpienia ilościowe badania wykorzystania informacji - bibliometria, informetria i webometria. Łącznie we wszystkich trzech analizowanych czasopismach zagadnieniom tym poświęconych było prawie $17 \%$ artykułów, przy czym w JASIS T problematyki tej dotyczyło w minionym roku prawie $29 \%$ wszystkich artykułów. O wadze tych badań w informatologii świadczy też poświęcenie im w minionych pięciu latach aż 6 przeglądów opublikowanych w ARIS\&T (10\% wszystkich przeglądów wydanych w latach 2007-2011).

Obszarem, w którym również lokuje się duża liczba prowadzonych współcześnie badań jest organizacja wiedzy, obejmująca różne metody i narzędzia organizowania dostępu do treści zasobów informacyjnych: wykorzystywanie folksonomii, automatyczne i manualne indeksowanie różnych typów zapisów wiedzy, opracowywanie i wykorzystywanie różnych schematów metadanych, rozwój metod automatycznej klasyfikacji i projektowanie ontologii, a także weryfikacja i formułowanie nowych koncepcji teoretycznych organizowania wiedzy. Zagadnieniom tym w trzech badanych czasopismach poświęcono łącznie 14,62\% wszystkich opublikowanych w nich ostatnio artykułów, w pięciu ostatnich rocznikach ARIS\&T dotyczyło jej natomiast 8,33\% przeglądów piśmiennictwa.

Równie duży i także wewnętrznie dość zróżnicowany jest nurt badań związanych ze współczesną komunikacją naukową: monitorowaniem jej intensywności za pomocą metod naukometrycznych, jej informatyczną infrastrukturą, rozwojem i rolą w niej ruchu open access, a także analizą form tekstów naukowych, która dostarczyć ma dane do skuteczniejszego wydobywania z nich, analizowania i agregowania danych naukowych. Tego rodzaju aspektom nowoczesnej komunikacji naukowej w badanych czasopismach poświęcono łącznie blisko 13\% publikacji, a w ARIS\&T w ostatnich pięciu latach ukazało się aż 9 (15\%) przeglądów piśmiennictwa badawczego z tego zakresu. Warto też zauważyć, że we wszystkich badanych czasopismach informatologicznych zagadnienia komunikacji naukowej wypełniają podobny odsetek artykułów. Można zatem sądzić, że problematyka ta budzi dziś duże zainteresowanie zarówno wśród badaczy specjalizujących się w zagadnieniach technologicznych, jak i wśród badaczy związanych z nurtem badań społecznych i humanistycznych w informatologii.

Wśród analizowanych artykułów stosunkowo mały odsetek stanowią publikacje z zakresu zarządzania informacją i wiedzą, w szczególności w środowisku biznesowym. Problematyce tej łącznie w trzech badanych czasopismach poświęcono 7,31\% artykułów, jednak w ARIS\&T ukazało się w ciągu ostatnich pięciu lat aż 7 przeglądów piśmiennictwa poświęconego różnym jej aspektom (11,67\%). Zarządzanie informacją i wiedzą nadal zatem należy do silnych nurtów badawczych współczesnej nauki o informacji. Trzeba też pamiętać, że wiele prac specjalistów informacji zajmujących się tą problematyką publikowane jest na łamach czasopism poświęconych wyłącznie zarządzaniu informacją czy zarządzaniu wiedzą. 
Analiza zawartości trzech wybranych czasopism wykazała też znaczącą liczbę publikacji dotyczących problematyki tzw. społecznego Webu (łącznie prawie 8\% wszystkich artykułów opublikowanych w JASIST, JIw i JDoc oraz aż 5 przeglądów piśmiennictwa w ARIS\&T - tj. ponad 8\% wszystkich przeglądów wydanych w ostatnich pięciu rocznikach). Problematykę tę wyodrębniono zatem jako wyraźnie kształtujący się nurt zainteresowań badawczych związanych zarówno z technicznymi jak i społecznymi aspektami funkcjonowania i wykorzystywania serwisów społecznościowych.

Tabela 5. Obszary badań najczęściej reprezentowane w JASIST w 2012 r. oraz w JIS i JDoc w latach 2011-2012

\begin{tabular}{|c|c|c|c|c|c|}
\hline L.P. & OBSZAR BADAŃ & 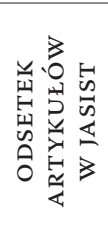 & 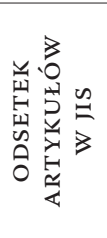 & 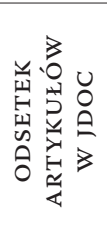 & 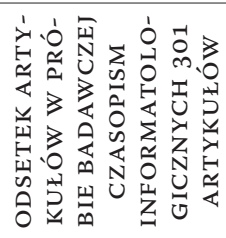 \\
\hline 1 & $\begin{array}{l}\text { TECHNOLOGIA INFORMACYJNA: metody } \\
\text { i oceny wyszukiwania informacji, NLP, data } \\
\text { mining, text mining, web mining, HCI }\end{array}$ & 43.45 & 56.62 & 5.48 & 37.87 \\
\hline 2 & $\begin{array}{l}\text { BADANIA UŻYTKOWNIKów: zachowania } \\
\text { i praktyki informacyjne, wyszukiwanie infor- } \\
\text { macji, wykorzystywanie Internetu, kompe- } \\
\text { tencje informacyjne (information literacy) }\end{array}$ & 24.14 & 15.66 & 28.77 & 22.59 \\
\hline 3 & $\begin{array}{l}\text { BADANIA ILOŚCIOWE: bibliometria, infor- } \\
\text { metria, webometria }\end{array}$ & 28.97 & 6.02 & 5.48 & 16.94 \\
\hline 4 & $\begin{array}{l}\text { ORGANIZACJA WIEDZY: społeczne indekso- } \\
\text { wanie - folksonomie, automatyczna klasy- } \\
\text { fikacja, ontologie, indeksowanie materiałów } \\
\text { niepiśmienniczych, zagadnienie teoretyczne }\end{array}$ & 11.72 & 15.66 & 16.44 & 14.62 \\
\hline 5 & $\begin{array}{l}\text { KOMUNIKACJA NAUKOWA: publikacje na- } \\
\text { ukowe, open access, e-nauka i informatycz- } \\
\text { na infrastruktura naukowa, struktura tekstu } \\
\text { naukowego }\end{array}$ & 13.10 & 13.25 & 12.33 & 12.96 \\
\hline 6 & $\begin{array}{l}\text { SPOŁECZNY WEB: sieci społeczne, dzielenie } \\
\text { się wiedzą, crowdsourcing }\end{array}$ & 9.66 & 10.84 & 1.37 & 7.97 \\
\hline 7 & $\begin{array}{l}\text { ZARZĄDZANIE INFORMACJĄ I WIEDZĄ: } \\
\text { zarządzanie dokumentami, praktyki infor- } \\
\text { macyjne, analiza i kontrola jakości danych, } \\
\text { komunikacja }\end{array}$ & 8.97 & 7.23 & 4.11 & 7.31 \\
\hline 8 & $\begin{array}{l}\text { NAUKA O INFORMACJI: teoria, podstawowe } \\
\text { kategorie badawcze (dokument, wiedza, } \\
\text { informacja), filozofia, epistemologia, meto- } \\
\text { dologia, historia, edukacja, badania }\end{array}$ & 6.21 & 4.82 & 4.11 & 5.32 \\
\hline 9 & $\begin{array}{l}\text { ANALIZA DOMEN WIEDZY: informacja } \\
\text { o zdrowiu, informacja biomedyczna i me- } \\
\text { dyczna, informacja społeczna, informacja } \\
\text { patentowa }\end{array}$ & 6.90 & 0.00 & 0.00 & 3.32 \\
\hline
\end{tabular}


W szczególny sposób w badanej próbie piśmiennictwa ukształtowały się ilościowe proporcje publikacji z zakresu badań metanaukowych dotyczących nauki o informacji: jej aksjologii, podstaw epistemologicznych, historii, teorii, centralnym kategoriom badawczym, metodologii, edukacji. Problematyka ta była wyraźnie i z podobną intensywnością obecna na łamach wszystkich trzech badanych czasopism - łącznie 5,32\% opublikowanych w nich artykułów, z czego najwięcej zarówno w wartościach bezwzględnych jak i w proporcji do innych obszarów tematycznych ukazało się w JASIs T (9 tekstów w 2012 roku, 6,21\% wszystkich artykułów opublikowanych w badanym okresie). Bardzo wysoką pozycję problematyka ta zajmuje w przeglądach publikowanych w ARIS\&T: poświęcono jej w ostatnich pięciu rocznikach aż 14 artykułów przeglądowych, co stanowi blisko $25 \%$ wszystkich opublikowanych w nich opracowań. Ta wzmożona uwaga skierowana na samą naukę o informacji w wymowny sposób potwierdza sygnalizowaną wcześniej potrzebę weryfikacji założeń i programu badawczego dyscypliny w dynamicznie zmieniającym się technologicznym i społecznym środowisku projektowania i prowadzenia usług, które zapewnić mają skuteczne i adekwatne udostępnianie zapisanej wiedzy.

Interesujące jest również dość duże zainteresowanie badaczy tzw. analizą domen, czyli pogłębioną analizą specyfiki zasobów wiedzy i potrzeb informacyjnych związanych z korzystaniem z niej w poszczególnych dziedzinach czy obszarach działalności. Tego rodzaju badania szczególnie licznie prezentowane były ostatnio na łamach JASIST - 10 artykułów dotyczących specjalistycznych usług informacyjnych, z czego aż 6 dotyczyło informacji medycznej, biomedycznej i o zdrowiu. Problematyka informacji o zdrowiu, informacji prawnej i informacji społecznej podejmowana była na łamach „Journal of Documentation”. Rozwój analizy domen jest też systematycznie monitorowany w ARIS\&T, gdzie problematyce tej w pięciu ostatnich latach poświęcono 6 przeglądów (10\%).

Tabela 6. Problematyka badawcza nauki o informacji omawiana w artykułach przeglądowych w Annual Review of Information Science and Technology w ostatnich pięciu rocznikach (2007-2011)

\begin{tabular}{|c|c|c|c|}
\hline \multirow[t]{2}{*}{ L.P. } & \multirow[t]{2}{*}{ OBSZAR BADAŃ } & \multicolumn{2}{|c|}{$\begin{array}{l}\text { ARIST } 2007-2011 \\
\text { VOL. } 41-45 \\
\text { WYSTCPIENIA } \\
\text { W } 60 \text { ARTYKU- } \\
\text { ŁACH } \\
\end{array}$} \\
\hline & & LICZBA & ODSETEK \\
\hline 1 & $\begin{array}{l}\text { ANALIZA DOMEN WIEDZY: informatyka chemiczna, geoinformatyka, } \\
\text { informacja edukacyjna, farmaceutyczna, o zdrowiu, publiczna }\end{array}$ & 6 & 10.00 \\
\hline 2 & Architektura informacji & 1 & 1,67 \\
\hline 3 & BADANIA ILOŚCIOWE: bibliometria, naukometria & 6 & 10.00 \\
\hline 4 & $\begin{array}{l}\text { BADANIA UŻYTKOwNIKów: codzienne zachowania informacyjne, } \\
\text { zachowania informacyjne w różnych obszarach wiedzy, wykorzystywa- } \\
\text { nie informacji }\end{array}$ & 11 & 18.33 \\
\hline 5 & Biblioteki i repozytoria cyfrowe & 1 & 1.67 \\
\hline 6 & Ekonomia informacji; e-gospodarka & 3 & 5.00 \\
\hline 7 & $\begin{array}{l}\text { KOMUNIKACJA NAUKOWA: współpraca naukowa, e-nauka, informa- } \\
\text { tyczna infrastruktura nauki, repozytoria open access, ewaluacja czaso- } \\
\text { pism naukowych struktura tekstu naukowego }\end{array}$ & 9 & 15.00 \\
\hline
\end{tabular}




\begin{tabular}{|c|c|c|c|}
\hline \multirow[t]{2}{*}{ L.P. } & \multirow[t]{2}{*}{ OBSZAR BADAŃ } & \multicolumn{2}{|c|}{$\begin{array}{l}\text { ARIST } 2007-2011 \\
\text { VOL. } 41-45 \\
\text { WYSTCPIENIA } \\
\text { W 6O ARTYKU- } \\
\text { ŁACH } \\
\end{array}$} \\
\hline & & LICZBA & ODSETEK \\
\hline 8 & $\begin{array}{l}\text { Nauka o informacji: teoria, podstawowe kategorie badawcze (doku- } \\
\text { ment, wiedza, informacja), filozofia, epistemologia, metodologia, } \\
\text { historia, edukacja, badania }\end{array}$ & 14 & 23.33 \\
\hline 9 & $\begin{array}{l}\text { ORG ANIZ ACJA WIEDZY: folksonomie, społeczne indeksowanie, spo- } \\
\text { łeczne adnotowanie, metadane (xML, RDF), ontologie, ogólna teoria } \\
\text { organizacji wiedzy }\end{array}$ & 5 & 8.33 \\
\hline 10 & Polityka informacyjna, podział cyfrowy, regulacje prawne & 4 & 6.67 \\
\hline 11 & SPOŁECZNY WEB: dzielenie się wiedzą, sieci społeczne & 5 & 8.33 \\
\hline 12 & TECHNOLOGIA INFORMACYJNA & 21 & 35.00 \\
\hline 1 & $\begin{array}{l}\text { Data mining, text mining, Web mining (badanie nastrojów, badanie } \\
\text { wątków tematycznych, analizy sieci społecznych) }\end{array}$ & 3 & 5.00 \\
\hline 2 & e-Administracja - narzędzia informatyczne & 1 & 1.67 \\
\hline 3 & HCI & 2 & 3.33 \\
\hline 4 & $\begin{array}{l}\text { NLP, semantyka, automatyczne streszczanie, automatyczny przekład, } \\
\text { automatyczne indeksowanie (język arabski, chiński, turecki), auto- } \\
\text { matyczna klasyfikacja }\end{array}$ & 3 & 5.00 \\
\hline 5 & Semantyczny Web, ontologie & 2 & 3.33 \\
\hline 6 & Systemy automatycznej identyfikacji autorów & 1 & 1.67 \\
\hline 7 & Systemy ekspertowe, sztuczna inteligencja & 2 & 3.33 \\
\hline 8 & Systemy GIS & 1 & 1.67 \\
\hline 9 & Systemy uczące się & 1 & 1.67 \\
\hline 10 & Systemy wspierania edukacji & 1 & 1.67 \\
\hline 11 & WYSZUKIWANIE INFORMACJI & 4 & 6.67 \\
\hline 13 & ZARZĄDZANIE INFORMACJĄ I WIEDZĄ, komunikacja w biznesie & 7 & 11.67 \\
\hline 14 & Źródła informacji, wiarygodność informacji, dostępność informacji & 1 & 1.67 \\
\hline
\end{tabular}

W analizowanej próbie artykułów największe skupienia tworzą badania w dziewięciu omówionych wyżej obszarach tematycznych. Na pozostałe 17 wyodrębnionych obszarów przypada niespełna $12 \%$ wszystkich tekstów opublikowanych w trzech najbardziej wpływowych międzynarodowych czasopismach z zakresu nauki o informacji. W tabeli 5 zestawione zostały obszary badań najczęściej prezentowanych w ostatnim czasie na łamach JASIST, "Journal of Information Science” i „Journal of Documentation”. Warto tu zwrócić uwagę na duże różnice dotyczące obecności problematyki coraz bardziej zaawansowanych technologii informacyjnych na łamach JA SIST i JIS oraz „Journal of Documemntation”. W szczególności JIs coraz wyraźniej specjalizuje się obecnie w problematyce informatycznej, co potwierdza również najniższy wśród analizowanych czasopism odsetek publikowanych na jego łamach prac z zakresu badań użytkowników. Z kolei „Journal of Documentation” poświęca problematyce technologicznej coraz mniej uwagi, oferując na swoich łamach miejsce również dla tematyki bibliologicznej i bibliotekoznawczej (zob. tabela 4). 
Tabela 7. Porównanie problematyki badań omawianej w ostatnich 5 latach w ARIST i problematyki artykułów opublikowanych w latach 2011-2012 na łamach JASIST, JIS i JDOC

\begin{tabular}{|c|c|c|c|}
\hline L.P. & OBSZAR BADAŃ & 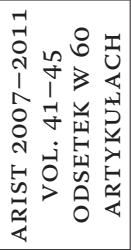 & 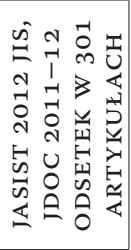 \\
\hline 1 & $\begin{array}{l}\text { ANALIZ A DOMEN WIEDZY: informatyka chemiczna, geoinformatyka, } \\
\text { informacja edukacyjna, farmaceutyczna, o zdrowiu, publiczna }\end{array}$ & 10.00 & 3.32 \\
\hline 2 & Architektura informacji & 1,67 & \\
\hline 3 & $\begin{array}{l}\text { BADANIA ILOŚCIOWE WYKORZYSTANIA INFORMACJI: bibliometria, } \\
\text { naukometria, webometria }\end{array}$ & 10.00 & 16.94 \\
\hline 4 & $\begin{array}{l}\text { BADANIA UŻYTKOWNIKów: codzienne zachowania informacyjne, } \\
\text { zachowania informacyjne w różnych obszarach wiedzy, wykorzystywa- } \\
\text { nie informacji }\end{array}$ & 18.33 & 22.59 \\
\hline 5 & Biblioteki cyfrowe, repozytoria cyfrowe & 1.67 & 1.66 \\
\hline 6 & Ekonomia informacji; e-gospodarka & 5.00 & \\
\hline 7 & $\begin{array}{l}\text { KOMUNIKACJA NAUKOWA: współpraca naukowa, e-nauka, informa- } \\
\text { tyczna infrastruktura nauki, repozytoria open access, ewaluacja czaso- } \\
\text { pism naukowych struktura tekstu naukowego }\end{array}$ & 15.00 & 12.96 \\
\hline 8 & $\begin{array}{l}\text { NAUKA O INFORMACJI: teoria, podstawowe kategorie badawcze } \\
\text { (dokument, wiedza, informacja), filozofia, epistemologia, metodologia, } \\
\text { historia, edukacja, badania }\end{array}$ & 23.33 & 5.32 \\
\hline 9 & $\begin{array}{l}\text { ORGANIZACJA WIEDZY: folksonomie, społeczne indeksowanie, spo- } \\
\text { łeczne adnotowanie, metadane (xML, RDF), ontologie, ogólna teoria } \\
\text { organizacji wiedzy }\end{array}$ & 8.33 & 14.62 \\
\hline 10 & Polityka informacyjna, podział cyfrowy, regulacje prawne & 6.67 & 1.66 \\
\hline 11 & SPOŁECZNY WEB: dzielenie się wiedzą, sieci społeczne & 8.33 & 7.97 \\
\hline 12 & $\begin{array}{l}\text { TECHNOLOGIA INFORMACYJNA: wyszukiwanie informacji, Data mi- } \\
\text { ning, text mining, Web mining, NLP, semantyka, automatyczne stresz- } \\
\text { czanie, automatyczny przekład, automatyczne indeksowanie (język } \\
\text { arabski, chiński, turecki), automatyczna klasyfikacja, HCI, Semantyczny } \\
\text { Web, ontologie, infrastruktura e-Administracji, sztuczna inteligencja, } \\
\text { systemy automatycznej identyfikacji autorów, ekspertowe, GIS, uczące } \\
\text { się, wspierania edukacji }\end{array}$ & 35.00 & 37.87 \\
\hline 13 & $\begin{array}{l}\text { USŁUGI INFORMACYJNE: serwisy Q\&A, społeczne serwisy przekładów, } \\
\text { wykorzystanie wirtualnej rzeczywistości w usługach informacyjnych }\end{array}$ & - & 1.99 \\
\hline 14 & ZARZĄDZANIE INFORMACJĄ I WIEDZĄ, komunikacja w biznesie & 11.67 & 7.31 \\
\hline
\end{tabular}

Nieco inaczej kształtuje się rozkład tematyczny przeglądów piśmiennictwa opublikowanych w ostatnich pięciu rocznikach ARIS\&T (tabela 6), co oczywiście wynika zarówno stąd, że analiza tego rocznika obejmowała znacznie dłuższy okres (pięć lat), jak i ze specyfiki tego wydawnictwa, w którym prezentowany jest stan badań w wybranych obszarach, obejmujący zwykle kilka lat wstecz. Warto jednak zauważyć, że w kwestiach podstawowych różnice rozkładu głównych nurtów badań w współczesnej nauce o informacji w świetle 
danych uzyskanych na podstawie analizy ARIS\&T i danych pochodzących z analizy JASIST, JIS i „Journal of Documentation” nie są duże. W obu przypadkach obszarami skupiającymi największą liczbę badań są technologia informacyjna i badania użytkowników; dwa kolejne intensywnie eksplorowane pola tematyczne stanowią ilościowe badania wykorzystania informacji i komunikacja naukowa (tabela 7).

\section{Wnioski końcowe}

Teoretyczne rozważania metanaukowe oraz rosnące w ostatnich kilku latach zainteresowanie jakościowymi badaniami zachowań użytkowników wskazują na dokonywanie się w nauce o informacji zwrotu w kierunku badań społecznych i pojmowania dyscypliny jako nauki zajmującej się zjawiskami informacyjnymi zachodzącymi w świecie społecznym, w tym przede wszystkim transferem wiedzy w kontekście kulturowym i społecznym. Analiza najnowszego piśmiennictwa uznawanego za reprezentujące naukę o informacji Information Science - nie potwierdzają jednak jednoznacznie takiego zwrotu. Wprawdzie łącznie na badania użytkowników oraz ilościowe badania wykorzystania informacji w różnych środowiskach przypada blisko 40\% artykułów opublikowanych w najważniejszych czasopismach dyscypliny, to również blisko 40\% artykułów dotyczy technologicznych aspektów przetwarzania i udostępniania różnych typów informacji i wiedzy różnego rodzaju użytkownikom. Nie ulega jednak wątpliwości, że problematyka badań zachowań informacyjnych użytkowników i użytkowania informacji w różnych dziedzinach wiedzy i życia codziennego jest coraz częściej prezentowana na łamach piśmiennictwa współczesnej nauki o informacji. Nie jest to zresztą tendencja nowa, analogiczną wykazały np. badania, na próbie artykułów opublikowanych w najważniejszych czasopismach międzynarodowych dyscypliny w 2004 r. (zob. Sosińska-Kalata, 2007), potwierdza ją też wiele badań innych autorów (zob. np. Aharony, 2011; Cronin, 2012).

Chociaż dwa główne nurty badań - technologiczny i ukierunkowany na użytkowników rozwijają się dynamicznie, o czym świadczy zarówno liczba poświęconych im publikacji jak i rozwój ich podstaw teoretycznych i metod badawczych, to wydaje się, że każdy z nich, tak jak dostrzegli White i Cain (1998), uprawiany jest niezależnie przez różne i coraz bardziej oddalające się od siebie środowiska badawcze. Problematyka badań użytkowników osadzonych w kontekście studiów społecznych zajmuje znacząco więcej miejsca w humanistycznie i społecznie ukierunkowanym „Journal of Documentation” (prawie 29\%), niż w coraz silniej technologicznie ukierunkowanym JIs (ok. 16\%), a także w JASIST (ok. 24\%). Równocześnie na łamach „Journal of Documentation" tematyka technologiczna dominująca w JASIS (ok.43\%) i jIS (ok. 57\%) reprezentowana jest przez zaledwie nieco ponad 5\% i zajmuje dopiero czwartą pozycję wśród najczęściej podejmowanych w tym najstarszym czasopiśmie nauki o informacji. Z kolei wysoka pozycja tematyki użytkowników na łamach JASIST (ok. 24\%) wiąże się z tym, że coraz częściej badania użytkowników dotyczą ewaluacji technologii interakcyjnych i projektowania systemów informacyjnych zorientowanego na użytkownika.

Przeprowadzona analiza zawartości trzech najważniejszych czasopism we współczesnej nauce o informacji jednoznacznie potwierdza duże zainteresowanie badaczy ilościowymi badaniami piśmiennictwa, komunikacji naukowej i komunikacji w Internecie (bibliometria, informetria, webometria - prawie 17\%), a także organizacją wiedzy (ok. 15\% - w większości 
badania związane z informatycznymi i społecznościowymi metodami organizowania dostępu do zasobów wiedzy cyfrowej) oraz komunikacją naukową (ok. 13\% - w większości problematyką komunikacji naukowej w Internecie oraz badaniami dotyczącymi możliwości algorytmizacji rozpoznawania elementów struktury tekstów naukowych).

Zwracające uwagę znaczne zainteresowanie w ostatnich latach metanaukową refleksją nad nauką o informacji (ok. 5\% publikacji wśród artykułów z lat 2011 i 2012 i aż 23\% artykułów w ARIST) może być wyrazem rosnącej dojrzałości metodologicznej dyscypliny, zwłaszcza jej nurtu humanistyczno-społecznego, jak i często w piśmiennictwie sygnalizowanej potrzeby rewizji koncepcji dyscypliny w obliczu z jednej strony coraz większego oddalania się od siebie środowisk badawczych nauki o informacji pojmowanej jako nauka o wykorzystywaniu wysokich technologii i nauki o informacji pojmowanej jako jedna z nauk o kulturze, a z drugiej strony - rosnącego zainteresowania zagadnieniami informacji ze strony licznych innych dyscyplin i podejmowania przez nie prób integracji pola badawczego w formie tzw. iSchools (zob. Wu et al., 2011).

\section{Bibliografia}

Aharony, N. (2011). Library and Information Science research areas: A content analysis of articles from the top 10 journals 2007-8. Journal of Library and Information Science 44 (1), 27-35.

ASIS\&T (2013). History of ASIS\& $\mathrm{T}$ - Timeline [online]. ASIS\&T - The Information Association for Information Age [14.11.2013], http://www.asis.org/history.html

Bates, M. J. (1999). The invisible substrate of information science. Journal of the American Society for Information Science 50 (12), 1043-1050.

Bates, M. J. (2012). The information professions: knowledge, memory, heritage [online]. Presented at Association of Library and Information Science Education conference, Dallas, TX, Jan. 18, 2012. University of California, Graduate School of Education and Information Studies [20.10.2012], http://pages.gseis.ucla.edu/faculty/bates/articles/pdf/InfoProfessions.pdf

Bojar, B. red. (2002). Stownik encyklopedyczny informacji, języków i systemów informacyjno-wyszukiwawczych. Warszawa: Wydaw. SBP.

Borko, H. (1968). Information science - What is it? American Documentation 19 (1), 3-5.

Buckland, M. (1999). The landscape of information science: the American Society for Information Science at 62. Journal of the American Society for Information Science 50 (11), 970-974.

Buckland M. (2012). What kind of science can Information Science be? Journal of the American Society for Information Science and Technology 63 (1), 1-7.

Brooks, B. (1980). The foundations of Information Science. Part 1. Philosophical aspects. Journal of Information Science 2 (3/4), 125-133.

Cisek, S. (2002). Filozoficzne aspekty informacji naukowej. Kraków: Wydaw. u.

Cisek, S. (2008). Nauka o informacji na świecie w XxI wieku: badania metanaukowe [online]. eLIS [18.11.2013], http://eprints.rclis.org/11098/

Cleverdon, C.W. (1991). The significance of the Cranfield tests of indexing languages. In: SIGIR '91: Proceedings of the 14th annual international ACM SIGIR conference on Research and development in information retrieval, New York, NY: ACM, 3-12

Cronin, Blaise (2012). The waxing and waning of a field: reflections on information studies education [online]. Information Research 17 (3) [16.10.2012], http://information.net/ir/17-3/paper529.html

Daniłowicz, Cz. (1994). Informatyka w programach kształcenia bibliotekoznawców. W: Kształcenie bibliotekarzy dla przyszłości. Warszawa: Wydaw. SBP, 153-163.

Dembowska, M. (1969). Dokumentacja i informacja naukowa. Zarys problematyki i kierunki rozwoju. Warszawa: SBP. 
Dembowska, M. (1977). Informacja naukowa i informatyka. „Przegląd Biblioteczny” 45 (2), 141-143.

Dembowska, M. red. (1978). Stownik terminologiczny informacji naukowej. Wrocław: Ossolineum.

Dembowska, M. (1991). Nauka o informacji naukowej (informatologia). Organizacja i problematyka badań w Polsce. Warszawa: IINTE

ELIS (2009). Encyclopedia of Library and Information Sciences. Eds. Marcia Bates \& M. Niles Maack. Boca Raton, London, New York: CRC Press, Taylor \& Francis Group.

Hjørland, B. (2011). The nature of information science and its core concepts [online]. Birger Hjørland intervention au colloque EPICIC, 8 avril University of Lyon 3 - France, ISKo France, Colloque sur l'épistémologie comparée des concepts d'information et de communication dans les disciplines scientifiques (EPICIC) [20.10.2012], http://www.epicic.org/sites/default/files/Hjorland.pdf

Janiak, M. (2010). Informacja naukowa w Polsce ba przełomie XX $i$ XXI wieku. Dynamika zmian w świetle piśmiennictwa. Kraków: Wydaw. UJ.

Larivière, V.; Sugimoto, C.R.; Cronin, B. (2012). A bibliometric chronicling of Library and Information Science's First Hundred Years. Journal of the American Society for Information Science and Technology 63 (5), 997-1016.

Meadows, J. (2009). Fifty years of uK research in information science. In: Information Science in Transition, ed. By. A. Gilchrist, London, Facet Publishing.

Manning, Ch.; Raghaven, P.; Schütze, H. (2008). Introduction to Information Retrieval. Cambridge University Press.

Nicholas, D. (2012). Researching the digital transition. In: B. Sosińska-Kalata, E. Chuchro i M. Luterek (red). Nauka o informacji (informacja naukowa) w okresie zmian. Warszawa: Wydaw. SBP 2012, Miscellanea Informatologica Varsoviensia, vol. 6, 17-31.

Otlet, P. (1934) Traité de documentation. Le livre sur le livre. Théorie et pratique. Bruxells: Editionses Mundaneum ,Palais Mondial 1934, available at http://lib.ugent.be/fulltxt/handle/1854/5612/ Traite_de_documentation_ocr.pdf

Pindlowa, W.; Krakowska, M. (2002). Badania statystyczno-analityczne czasopism polskich z zakresu informacji naukowej. Zagadnienia Naukoznawstwa 1-2, 101-111.

Popper, K. (1999). Droga do wiedzy: Domysty i refutacje, Wyd. pwn, Warszawa 1999.

Salton, G. (1975). SMART. Automatyczny system wyszukiwania informacji. Warszawa PWN.

Sapa, R. (2013). Podejście holistyczne w nauce o informacji. W: B. Sosińska-Kalata, E. Chuchro i M. Luterek (red). Nauka o informacji (informacja naukowa) wokresie zmian. Warszawa: Wydaw. SBP 2012, Miscellanea Informatologica Varsoviensia, vol. 6, 63-79.

Saracevic, T. (1999). Information Science. Journal of the American Society for Information Science 50 (12), 1051-1063.

Schrader, A. M. (1984). In search of a name: Information Science and its conceptual antecedents. Library and Information Science 6, 227-271.

Sosińska-Kalata, B. (2004). Czym jest dziś nauka o informacji? Tytułem wstępu. W: B. Sosińska-Kalata, K. Materska i W. Gliński (red.) Społeczeństwo informacyjne i jego technologie. Warszawa: Wydaw. SBP, 9-12.

Sosińska-Kalata, B. (2007). Współczesne oblicze nauki o informacji w Polsce i za granicą. W: Studia $z$ informacji naukowej i dyscyplin pokrewnych. E. Gondek i D. Pietruch-Reizes (red.). Katowice: Wyd. uś, 93-119.

Świgoń, Marzena (2012). Zarzadzania wiedza i informacją. Olsztyn: Wydaw. uwM.

Wilson, T. D. (2002). Philosophical foundations and research relevance: issues for information research [online]. Keynote address delivered to CoLIs4 - Fourth International Conference on Conceptions of Library and Information Science: Emerging Frameworks and Method, University of Washington, Seattle, USA, July 21 to 25. Professor Tom Wilson Website [14.11.2013], http://informationr.net/ tdw/publ/papers/COLIS4.html 
White, H.; McCain, K. (1998). Visualizing a discipline: An author co-citation analysis of information science, 1972-1995. Journal of the American Society for Information Science 49 (4), 327-355.

Wu, D.; He, D.; Jiang, J.; Dong, W.; Thien Vo, K. (2011). The state of iSchools: an analysis of academic research and graduate education. Journal of Information Science 38 (1), 11-36.

Zins, Ch. (2006). Knowledge map of information science: issues, principles, implications. In: Advances in Knowledge Organization 10, 141-149.

Zins, Ch. (2007a). Classification schemes of information science: twenty-eight scholars map the field. Journal of the American Society for Information Science and Technology 58 (5), 645-672.

Zins, Ch. (2007b). Knowledge map of information science. Journal of the American Society for Information Science and Technology 58 (4), 526-535.

Prof.dr hab. BARBARA SOSIŃSKA-KALATA jest pracownikiem naukowym Uniwersytetu Warszawskiego, kierownikiem Zakładu Systemów Informacyjnych w Instytucie Informacji Naukowej $i$ Studiów Bibliologicznych Uniwersytetu Warszawskiego. Zajmuje się problematyka nauki o informacji, w szczególności organizacji wiedzy oraz teoretycznymi podstawami nauki o informacji. Jest autorka ponad blisko 200 publikacji, w tym kilkunastu książek, spośród których do najważniejszych należą Modele organizacji wiedzy w systemach wyszukiwania informacji o dokumentach (Warszawa 1999), Klasyfikacja. Struktury organizacji wiedzy, piśmiennictwa i zasobów informacyjnych (Warszawa 2002) oraz zainicjowany w 2004 r. cykl prac zbiorowych „Miscellanea Informatologica Varsoviensia”, w którym ukazało się dotychczas sześć tomów (2004, 2005, 2006, 2008, 2012, 2013$).$ W 2011 r. zainicjowała organizacje przez IINSB uW cyklicznej konferencji międzynarodowej „Nauka o informacji w okresie zmian”, której druga edycja odbyła się w 2013 r. Od 2013 r. jest redaktorem naczelnym pótrocznika „Zagadnienia Informacji Naukowej - Studia Informacyjne". 